\title{
Relational embeddedness and firm growth: \\ Comparing spousal and sibling entrepreneurs
}

\section{Forthcoming in Organization Science}

\author{
Miriam Bird \\ University of St. Gallen \\ Global Center for Entrepreneurship \& Innovation \\ Dufourstrasse 40a \\ 9000 St. Gallen \\ Switzerland \\ Email: miriam.bird@unisg.ch \\ Phone: 0041712247110 \\ Fax: 0041712247101 \\ $\&$ \\ Stockholm School of Economics \\ Center for Entrepreneurship and Business Creation \\ Box 6501 \\ 11383 Stockholm \\ Sweden
}

\author{
AND \\ Thomas Zellweger* \\ University of St. Gallen \\ Center for Family Business \\ Dufourstrasse 40a \\ 9000 St. Gallen \\ Switzerland \\ Email: thomas.zellweger@unisg.ch \\ Phone: 0041712247100 \\ Fax: 0041712247101
}

*corresponding author

Acknowledgments: We gratefully acknowledge the excellent suggestions and support provided by

Wesley Sine and three anonymous reviewers. We thank Howard Aldrich, Karin Hellerstedt, Nadine

Kammerlander, Jeroen Neckebrouck, Mattias Nordqvist, Philipp Kim, Pankaj Patel, Bill Schulze, Marc

van Essen and Karl Wennberg for thoughtful comments on earlier versions of the manuscript. 


\title{
Relational embeddedness and firm growth:
}

Comparing spousal and sibling entrepreneurs

\begin{abstract}
Integrating relational embeddedness arguments with Penrosean growth theory, we compare the growth of firms run by spousal entrepreneurs with firms run by sibling entrepreneurs. We theorize that trust, identification, and mutual obligations - the three facets of relational embeddedness - are more pronounced in spousal teams than in sibling teams, which provides spousal teams with advantages over sibling teams in generating firm growth. Probing a sample of all private firms in Sweden over a three-year period, we find support for this conjecture. Exploring boundary conditions to this baseline relationship, we also find that firm age weakens the growth advantages of spousal teams over sibling teams and that industry experience heterogeneity within the entrepreneurial team reinforces these growth advantages. These results provide important contributions for research on firm growth, the social embeddedness of firms, entrepreneurship, and family business.
\end{abstract}

Keywords: Entrepreneurial teams, family firms, firm growth, relational embeddedness, 


\section{Introduction}

Firm growth is a foundational topic of management (Greve 2008, Kor and Mahoney 2004) and entrepreneurship research (Delmar et al. 2003, Wennberg et al. 2016). Growth is important for the establishment of firms (Shane 1996) and often constitutes a signal of success (Eisenhardt and Bird Schoonhoven 1990). Reaching a specific firm size is particularly important for private firms since growth increases a firm's market power and secures competitiveness against large rivals (Audretsch et al. 2014, Lockett et al. 2011, Penrose 1959).

In the various approaches seeking to explain firm growth, Edith Penrose's work (1959) stands out. She argued that firm growth is strongly influenced by the quality of relationships among the firm's entrepreneurial team members (Kor et al. 2007). This argument is also in line with the relational embeddedness perspective (Granovetter 1992), which emphasizes that relationships can serve as important resources for achieving economic goals (Blatt 2009, Granovetter 1992, Nahapiet and Ghoshal 1998). In particular, the three forms of relational embeddedness — namely trust, identification, and obligations among entrepreneurial group members — should help shed light on how relationships become important resources for attaining firm growth (Blatt 2009, Eisenhardt and Bird Schoonhoven 1990).

Members of entrepreneurial teams very often share familial relationships (Ruef 2010a, Ruef et al. 2003), and the firm's exposure to familial relationships within the entrepreneurial team has the potential to either support or constrain a firm's economic action (Aldrich and Cliff 2003, Granovetter 1985, Miller et al. 2011). Unfortunately, however, family embeddedness research has treated the family as a largely uniform type of social affiliation, paying little attention to the distinct relational embeddedness of various family types prevalent in entrepreneurial teams, where members are related by either social ties (e.g., spousal teams) or by blood (e.g., sibling teams) (Parsons 1949, Ruef 2010b, Segalen 1986). With our paper, we thus propose a systematic link between the relational embeddedness of spousal teams versus sibling teams and private firm growth.

Comparing the relational embeddedness of spousal teams and sibling teams, we suggest that trust, identification, and mutual obligations are more pronounced for spousal teams than for sibling teams such that spousal teams achieve higher firm growth than sibling teams. Drawing from the literatures on social 
embeddedness (Granovetter 1992, Nahapiet and Ghoshal 1998), family sociology (Parsons 1949), and entrepreneurial teams (Aldrich and Cliff 2003, Ruef 2010a, Yang and Aldrich 2014), we suggest that the baseline advantage of spousal over sibling teams in generating firm growth should be contingent on firm age, number of owners, and heterogeneity in industry experience within the team.

We employ an unusually rich multilevel propensity score-matched sample of 4,900 private firms and their owner-managers that were in existence in Sweden between 2004 and 2007. We contribute to the literature on firm growth by showing that growth is determined by the relational embeddedness of a firm's entrepreneurial team (Garnsey 2002, Penrose 1959). Our paper also adds to the family embeddedness literature (Aldrich and Cliff 2003, Jennings et al. 2014, Miller et al. 2011) by showing that family embeddedness has a disparate effect on growth depending on family type. We thus apply family embeddedness arguments beyond the founding context and to the family team level (Aldrich and Cliff 2003). Finally, we contribute to the literature on entrepreneurial teams (Ruef 2010a, Yang and Aldrich 2014) by showing that entrepreneurial team composition and teams' relational embeddedness (Blatt 2009) have a causal impact on firm growth not only at founding but also in later firm stages (Eisenhardt and Bird Schoonhoven 1990).

\section{Entrepreneurial Teams, Relational Embeddedness, and Firm Growth}

Among the multiple approaches used to explain firm growth, Penrose's comprehensive work occupies a towering position (Penrose 1952, 1955, 1959). Penrose (1959) argued that a theory of firm growth should account for entrepreneurial team members' human motivations and conscious human decisions associated with exploiting firms' underutilized resources. Penrosean growth theory and the resource-based view coincide in that they see resources as the central building blocks of a firm's economic success (Kor and Mahoney 2004, Lockett et al. 2011). While the resource-based view specifies the attributes of resources that are most conducive to achieving a sustainable competitive advantage (Barney 1991, Barney et al. 2001), Penrosean growth theory suggests that access to and the efficient deployment of resources are central for growth (Gilbert et al. 2006), especially for resource-constrained entrepreneurial firms (Kor and Mahoney 2004, Stinchcombe 1965). Much of the literature on entrepreneurial firm growth has drawn from Penrose's groundbreaking work and has explored various facets of firm growth, such as the impact of firm age (Delmar et al. 2003, Wennberg et al. 2016), firm size (Davidsson et al. 2010), innovation (Audretsch et al. 2014), slack resources (Bradley et al. 
2011), internationalization (Rodríguez and Nieto 2016), and entrepreneurs' growth aspirations (Delmar and Wiklund 2008). Scholars have also explored the role of a firm's environment in relation to firm growth, such as industry characteristics (Audretsch 1995) and the firm's location (Almus and Nerlinger 1999) (for recent reviews of this vast literature, refer to Davidsson et al. [2010] and Wiklund et al. [2009]). Still other studies have investigated the link between network ties and firm growth, primarily employing structural embeddedness arguments (Nahapiet and Ghoshal 1998) to explain how social networks (Batjargal et al. 2013, Brüderl and Preisendörfer 1998, Galaskiewicz et al. 2006, Stam and Elfring 2008) and interorganizational alliances (Davidsson et al. 2010, Peng et al. 2008, Stuart 2000) contribute to firm growth. Further, Brïderl and Preisendörfer (1998) as well as Arregle et al. (2007) suggested that familial resources, such as family networks and emotional support, positively influence the growth of newly founded firms.

Going back to Penrose's (1959) foundational work on firm growth, however, leads us to recognize that social relationships among entrepreneurial team members are central for growth. Acknowledging that "there are difficulties attendant upon the rapid expansion of the activities of a group of individuals bound together by intricate and delicate relationships" (Penrose 1959, p. 43), Penrose saw firm growth as being grounded in the social relationships of the entrepreneurial team, with the quality of those relationships playing a central role in firm growth. In line with Penrose (1959) and for the purpose of our study, we thus define an entrepreneurial team as two or more individuals who are engaged in the management and ownership of a private firm.

The importance of the entrepreneurial team and the quality of relationships among team members is particularly visible in Penrose's discussion of the team-level prerequisites for firm growth, such as the importance of a collectively shared sense of purpose in the team, confidence in other team members, and the quality of cooperation, for which she deemed knowledge and experience from working with each other to be critical (Penrose 1959, pp. 39-50, Lockett et al. 2011). Also, the literature on entrepreneurial teams has recognized that social relationships have a causal effect on organizational outcomes. For instance, prior research has explored how the strength and diversity of network ties within the entrepreneurial team influence organizational outcomes, such as innovation (Ruef 2002), and has shown that interpersonal trust among team members has a positive influence on firm growth (Eisenhardt and Bird Schoonhoven 1990). 
Penrose's view of firm growth can thus be linked to more recent work on relational embeddedness (Blatt 2009, Granovetter 1992, Nahapiet and Ghoshal 1998). Relational embeddedness is defined as the "actual and potential resources embedded with, available through, and derived from the network of relationships possessed by an individual or a social unit" (Nahapiet and Ghoshal 1998, p. 243). Hence, while structural embeddedness concerns the "impersonal configuration of linkages between people or units" (Nahapiet and Ghoshal 1998, p. 244) - that is, the broader networks of aggregate social relationships - relational embeddedness denotes individuals' personal relationships with other individuals, such as members of an entrepreneurial team (Bird and Wennberg 2016). Relational embeddedness emphasizes the "assets created and leveraged through relationships" (Nahapiet and Ghoshal 1998, p. 244), and these assets allow relationships to become a resource for achieving economic goals, such as firm growth.

\section{The Role of Trust, Identification, and Mutual Obligations in Firm Growth}

A link between relational embeddedness and firm growth appears plausible in light of conceptual arguments about the role of trust, identification, and obligations - the three facets of relational embeddedness (Blatt 2009, Granovetter 1992, Nahapiet and Ghoshal 1998) — and firms' economic action (Bolino et al. 2002, Moran 2005, Tsai and Ghoshal 1998).

Trust has been defined as a team member's willingness to accept vulnerability based on the expectation that other members will not abuse that vulnerability (Rousseau et al. 1998). When people trust one another, they are more likely to share proprietary and tacit information as well as information that is highly accurate, comprehensive, and timely (Kale et al. 2000, Uzzi 1996). In trusted relationships, people also feel safe expressing differences of opinion (Dyer and Chu 2012), which should support in-depth discussions of growth options and the formation of a joint vision for the firm (Baum et al. 2001). Trust also facilitates cooperation (Nahapiet and Ghoshal 1998) and leads to what Knez and Camerer (1994) called an "expectational asset," which describes how group members can count on each other to solve thorny problems that require cooperation and coordination among members, such as growing a firm (Penrose 1959). For instance, Eisenhardt and Bird Schoonhoven (1990) found that entrepreneurial team members' previous experience working together has a positive impact on sales growth and reflects interpersonal trust within the team. Trust also reduces the likelihood of opportunistic behavior among team members, which should support joint efforts and team 
members' willingness to exchange information (Blatt 2009) and eventually even pool resources that are unavailable in arm's length relationships (Kale et al. 2000, Uzzi 1997). In sum, trust among entrepreneurial team members should support growth because it deepens information exchange, increases the effectiveness of cooperation, and limits opportunism among team members (Nahapiet and Ghoshal 1998).

Identification, the second facet of relational embeddedness, is the process "whereby individuals see themselves as one with another person or group of people" (Nahapiet and Ghoshal 1998, p. 256). Team members who identify with each other incorporate the team in their self-concept and typically share values, narratives, behaviors, and goals with other members (Blatt 2009, Pratt 1998). These shared premises result from seeing the team and the team's activities as a statement of who one is (Ashforth and Mael 1989). Identification among team members is thus supportive of growth because planning for growth requires a collectively shared goal (Penrose 1959). Identification with a group also supports growth by raising group members' concern for collective processes (Dutton et al. 1994). For instance, because identified group members share certain premises for decision making, they are likely to respond to a given contingency in the same way (Blatt 2009). This predictability facilitates coordinated resource allocation toward a goal (Penrose 1959). As such, identification provides shared premises for decision making and also offers a rallying ground for team members to cooperate and work for the collective (Tsai and Ghoshal 1998), which is essential for the growth of private firms that cannot afford to be distracted by unproductive collaboration among team members (Davidsson et al. 2006). Finally, identification improves mutual understanding among team members (Blatt 2009). As outlined by Le Breton-Miller et al. (2011), identification leads to a homogenization of opinions and priorities, thereby supporting the transfer of ideas and knowledge (Bolino et al. 2002), which enables entrepreneurial companies to rapidly seize growth opportunities in coordinated ways (Blatt 2009). Identification should thus resemble what Weick (1995) called the "collective mind" of a team (see also Bolino et al. 2002), which assists organizational members in understanding and acting upon their experiences in a common way (Blatt 2009, Pratt 1998). In sum, identification among entrepreneurial team members supports growth because it provides a shared sense of purpose and a concern for collective processes and outcomes, and it improves mutual understanding among members. 
Finally, obligations (Blatt 2009, Nahapiet and Ghoshal 1998), sometimes also referred to as feelings of closeness or interpersonal solidarity (Moran 2005), determine the expectations and reciprocal obligations within a group (Coleman 1990). Obligations thus serve as individuals' motivation for and commitment to enacting common goals (Adler and Kwon 2002) either because people monitor each other and sanction those who violate the norms (i.e., obligations out of normative commitment) (Coleman 1990, Putnam 1993) or because such obligations are associated with feelings of closeness, friendship, respect, and even affection (i.e., obligations out of affective commitment) (Nahapiet and Ghoshal 1998). Obligations - regardless of whether they result from affective or normative considerations - drive firm growth by nurturing organizational members' confidence that others will follow through with their promises and that team members can rely on one another (Blatt 2009), a critical driver of firm growth (Penrose 1959). When team members rely on one another, the team is more likely to engage in self-help and bootstrap resources (Ebben and Johnson 2006), thus providing the firm with resources that are unavailable in less cohesive groups (Ensley et al. 2002). Thus, obligations among team members also represent a commitment to continuity for a collective project by mitigating uncertainty about whether team members will fulfill expectations (McGrath et al. 1995). Finally, obligations drive firm growth by cultivating relational exchange norms, such as benevolent or altruistic resource transfers. Uzzi (1996) suggested that obligations extend benefits to partners and invite the receiving partner to reciprocate at a later point in time, thus allowing for greater flexibility in exchange relationships (Ben-Porath 1980). In sum, obligations among team members are positive for firm growth by facilitating a more comprehensive discussion of growth options, building the sense that team members can rely on one another, and nurturing relational exchange norms. Taken together, we propose that by nurturing trust, identification, and obligations among team members, relational embeddedness facilitates the growth of private firms (Eisenhardt and Bird Schoonhoven 1990, Penrose 1959, Uzzi 1997).

\section{Relational Embeddedness of Spousal versus Sibling Teams and Firm Growth}

To date, family embeddedness research has treated "family" as a largely uniform social system (Aldrich and Cliff 2003), and some studies have used degree of family involvement in governance as a proxy for family embeddedness (Miller et al. 2011). However, from family sociology and family business studies we know that relational embeddedness varies depending on family types (e.g., Matzek et al. 2010, Schulze et al. 2001), 
particularly between what Parsons (1949) called a family of procreation (i.e., when members are linked by affinity, often marriage) and a family of orientation (i.e., when members are linked by consanguinity) (Furman and Buhrmester 1985, Raffaelli 1992, Segalen 1986). This distinction between core family types is reflected in teams of spousal and sibling entrepreneurs.

Spousal teams. Spousal teams represent the most common type of entrepreneurial team, with Ruef (2010a) finding that more than $50 \%$ of all entrepreneurial teams in the United States are composed of spousal couples. Trust is typically high among spousal team members because the firm represents the most vital and undiversified source of income for both spouses and serves to finance a shared household and eventually even child rearing (Becker 1973). Often, spouses not only share resources but even pool them both in the private and business spheres (Matzek et al. 2010). Spousal teams are thus interdependent and experience a harmony of interests that limits opportunistic behavior (Parsons 1949). ${ }^{1}$ For instance, Ruef (2010b) found that when intimate ties among entrepreneurial team members exist, such as between spouses, there is little evidence of free riding within the team. Moreover, spouses often have frequent and close interactions both at home and at work, which "permit actors to know one another, to share important information, and to create a common point of view" (Tsai and Ghoshal 1998, p. 465), thus enhancing the effectiveness of collaboration when working toward a collective goal, such as firm growth (Lockett et al. 2011, Penrose 1959).

Identification among spousal entrepreneurial team members should be pronounced, especially because spouses often opt into the relationship based on congruent values and goals (Matzek et al. 2010, Parsons 1949). Indeed, Ruef (2010a) suggested that spouses fulfill many requisites of shared identity that are otherwise generated through (choice) homophily. As a result of this matching process and also due to the many shared experiences both at work and at home, spouses typically have a deep understanding of each other and develop a collectively shared point of view and cumulative plans about how to grow the firm (Penrose 1959).

Obligations should also be pronounced among spousal teams. Since members engage in a spousal team out of affinity, the spousal relationship generally embodies loyalty and care (Segalen 1986), and Parsons (1949, p. 252) even called the spousal team a "solidarity unit." In contrast to adult siblings, for instance, who often share a history not only of companionship but also of conflict and rivalry (Gordon and Nicholson 2008), spouses tend to exhibit marked and sometimes even selfless mutual support as well as 
joint problem-solving capabilities (Sullivan et al. 2012). These characteristics are critical drivers of firm growth in the context of private firms wherein members of the entrepreneurial team have to be able to rely on each other (Penrose 1959). Further, these obligations within spousal teams are nurtured by affective considerations since a person's spouse often represents his or her most intimate friend (Ketokivi 2012, Swidler 2003), which makes alternative sources of support less attractive (Coleman 1990). Support among spouses is also motivated by normative motivations, such as the societal norm that spouses should seek compromise and maintain unanimity (Belenzon et al. 2015). Relatedly, Yang and Aldrich (2014) reported that compared to other forms of kinship, spousal relationships are deeply imbued with symbolic displays of accountability, typically reflecting common gendered roles of men as "breadwinners" and women as “caretakers” (Nock 1998, Ridgeway 2011). Moreover, via interaction across private and professional realms, spouses can readily enforce implicit promises of support and sanction the breach thereof since a lack of support in one domain likely impacts the other domain (Matzek et al. 2010, Muske et al. 2009). In sum, spousal teams in business typically exhibit relational attributes that enhance trust, identification, and obligations of support, which should positively affect firm growth.

Sibling teams. We expect that trust among sibling teams will be lower than among spousal teams, leading to lower growth for firms run by siblings as opposed to firms run by spouses. ${ }^{2}$ Because siblings are less likely to cohabit than spouses (Brannon et al. 2013), information exchange among sibling teams should be shallower than what is typically observed for spousal teams, who typically share a job and household and for whom the boundaries between professional and private life are particularly porous (Matzek et al. 2010). While the financial position of spousal entrepreneurs is inextricably linked to the undiversified wealth and income they derive from their firm, sibling entrepreneurs often benefit from the income of their respective spouses. In consequence, the economic well-being of the individual sibling is less contingent on the growth of the firm, which means that siblings are less interdependent compared to spouses and thus experience a lower harmony of interests that would limit opportunistic behavior. For sibling entrepreneurs, the firm is more apt to serve as an instrument to generate private benefits for the individual sibling and his or her immediate nuclear family at the expense of the firm's economic resource base and growth (Pollak 2003). 
Moreover, sibling relationships do not necessarily exist because of affinity, particularly among adult siblings (White 2001), thus differentiating sibling relationships from spousal relationships for which affinity typically represents a central attribute. Sibling relationships typically not only entail companionship and admiration but also quarreling, antagonism, and rivalry (Furman and Buhrmester 1985). Researchers have even considered conflict as a defining feature of the sibling relationship (e.g., Furman and Buhrmester 1985, Raffaelli 1992), and adult siblings sometimes carry a lifelong history of jealousy and critical family baggage (Gordon and Nicholson 2008), which undermines cohesion and trust among siblings (White, 2001). Even though the unconditional existence of blood ties establishes an inevitable affiliation between siblings and thus limits the likelihood of complete withdrawal from the relationship (White 2001), the delicacy of sibling relationships thus threatens to undermine the teamwork valuable for firm growth.

We also expect the level of identification among sibling teams to be lower than among spousal teams. Individuals generally do not consider their siblings to be core family because the "sibling relationship is the structural basis for neither the formation of families nor their continuation" (Davidoff 2006, p. 18). As a result, siblings should be less concerned about developing a shared sense of purpose. This view is reflected in Le Breton-Miller et al.'s (2011) argument that individuals are most loyal to and supportive of the group to which they are most closely tied and thus identify with (Ashforth and Mael 1989), such as one's own nuclear family (Parsons 1949). Indeed, there is an abundance of shocking illustrations (see for instance, Gordon and Nicholson 2008) of siblings in business engaging in unseemly battles over the direction of the firm and seeking to divert resources away from the joint venture.

Finally, we maintain that mutual obligations are less salient within sibling teams compared to spousal teams. Siblings who are in business together typically face a loyalty conflict in terms of whether to prioritize the conjugal family or the sibling relationship when it comes to allocating support, with the conjugal family typically taking precedence in Western culture (Ketokivi 2012, Swidler 2003). This preference for one's own conjugal family is because sibling relationships entail involuntary membership; social comparison (Raffaelli 1992); and competition for parental love, attention, and resources (McHale et al. 2012). Additionally, norms associated with social support and related expectations and sanctioning mechanisms are less stringent for sibling teams than for spousal teams. Conflicts are sometimes even seen as inevitable and natural among 
siblings (Brody 1998), making mutual support and altruistic exchanges less likely (Schulze et al. 2001). Compared to spouses with pronounced obligations of mutual support, siblings are less likely to feel that they can rely on each other, which should lead to a growth disadvantage for sibling teams compared to spousal teams. Taking these arguments together, ceteris paribus, we thus expect that sibling teams in contrast to spousal teams in business exhibit lower levels of trust, identification, and mutual obligations, which should lead to higher growth rates for firms run by spouses than for firms run by siblings. More formally, we propose:

HYPOTHESIS 1 (H1). Firms run by spousal teams exhibit higher firm growth than firms run by sibling teams.

\section{The Moderating Impact of Firm Age}

In exploring the boundaries of our baseline prediction, we propose that firm age will weaken the relational advantages of spousal teams as well as weaken the relational disadvantages of sibling teams such that firm age negatively moderates our baseline relationship. Young firms face complex challenges as they have yet to acquire and assemble a stable resource base, have not fully established relationships with suppliers and customers, and often operate in unstable environments (Stinchcombe 1965). Thus, the young firm context generally spurs not only excitement but also frustration, stress, and anxiety within the entrepreneurial team (Blatt 2009) and often leads to setbacks with regard to the venture's economic success. To grow young firms, entrepreneurial team members must thus be willing to support each other, improvise, jointly search for solutions, pledge private assets to the business, and be aligned with the strategy they pursue (Cooper et al. 1994). These relational embeddedness attributes are typical for spousal teams, as discussed above, and thus equip such teams with important capabilities and motivations to grow young firms. However, these relational qualities of spousal teams, which are particularly supportive of growth when a firm is young, are likely to become less important and even destructive for growth as the firm matures (Garnsey 2002). For instance, with increasing firm age, a firm can become over-embedded (Uzzi 1997) in the spousal entrepreneurs' relationship, thereby reducing the flow of new ideas so that "ties that bind may also turn into ties that blind" (Powell and Smith-Doerr 1994). Also, as firms mature, they are usually characterized by more stable business models and operating processes (Stinchcombe 1965), and decision making generally has to be delegated to employees. Spousal teams are likely to experience this shift toward established routines and bureaucratic organization as a 
constraint given their typically informal and intimate ways of collaborating. The formalization of structures and decision making in a maturing firm predefines responsibilities and behavior among team members (Blatt 2009), which reduces the importance of improvisation and helping (Grant and Asforth 2008).

Applying these considerations about firm age and growth to sibling teams points to opposite contingency effects. The typical limitations to firm growth embedded in sibling relationships as opposed to spousal relationships, including relational tension, goal divergence, and lower levels of solidarity, should be particularly destructive for the growth of young firms. This is because young — and thus often fragile - firms cannot afford distractions caused by conflicts, lack of shared vision, and goal incongruence at the helm of the firm if they want to grow (Eisenhardt and Bird Schoonhoven 1990). Indeed, when firms are young, personal relationships (not least between the entrepreneurial team members themselves) matter most. For example, Blatt (2009) proposed that the greater the novelty a team faces, the more important but also the more daunting the effort to form and sustain relationships becomes. In contrast, in more established firms, ties with key stakeholders, such as employees, customers, and suppliers, are time-honored and proven (Greene and Brown 1997). Indeed, with advancing firm age, the establishment of trust through relationships - an embeddedness attribute siblings teams typically have more trouble with—becomes less important for growth (Stinchcombe 1965). Additionally, mature firms often have to develop some division of labor, which should reduce the likelihood of overlapping responsibilities and confrontation among siblings. Likewise, mature firms often establish formal control systems that measure performance (Baron et al. 1999), which raises the visibility of individual performance and sets limits to opportunistic behaviors among siblings. Finally, older firms often have to set up standardized planning and budgeting systems that help align otherwise incongruent goals and strategic preferences, which is supportive of firm growth (Penrose 1959). In summary, we expect that the growth advantage of spousal teams over sibling teams should weaken with firm age. We thus posit the following:

HYPOTHESIS 2 (H2). Firm age weakens the growth advantage of firms run by spousal teams compared to firms run by sibling teams.

\section{The Moderating Impact of Number of Owners}

We also propose that an increased number of owners should undermine spousal entrepreneurs' growth advantages, whereas it should help sibling teams overcome their growth disadvantages. With regard to spousal 
teams, we expect that a large number of owners is likely to make sharing of fine-grained information and exploiting such information more difficult because information sharing becomes impersonal and more formal among owners, thereby slowing down team members' access to and use of intimate information, which are important for growth (Penrose 1959). An increasing number of owners should also make it less likely for spouses to be able to build the firm primarily by themselves and for themselves and to be able to pass the firm on to the next generation within the family, a goal cherished by many couples who are in business together (Danes and Morgan 2004) and a strong motivator to make the firm more successful (Belenzon et al. 2015). Also, with an increasing number of owners, spouses are likely to find it less natural to develop and maintain a joint vision for the firm because spouses may be split among themselves when additional owners join the firm (Buchanan and Badham 2008). Alternatively, a "we against them" atmosphere may result, whereby the spouses seek to uphold their unique group identity and interaction and coalesce against external owners who seek to exercise authority and influence strategy (Dacin et al. 1999, Schulze et al. 2003). In both cases, it is likely to become more challenging to develop a collective point of view for the firm and thus to be able to plan and execute growth strategies (Penrose 1959). Moreover, an increasing number of owners should disrupt mutual solidarity among spouses as relationships among members of larger teams tend to become less personal on average (Moody and White 2003). In sum, number of owners should undermine the relational embeddedness advantages of spousal teams.

In contrast, an increasing number of owners in firms run by siblings should help manage sibling feuds and keep such conflicts within acceptable scope, thereby helping stabilize fragile sibling relationships. This mitigation of conflicts occurs because a higher number of owners decreases the "direct connectedness" between siblings and therefore also weakens direct rivalries and conflicts between them (Moody and White 2003). Thus, an increasing number of owners should help reduce conflicts and eventually even allow a team to harness the advantages of more comprehensive decision-making and thus turn destructive relational conflict into functional task conflict (Ensley et al. 2002). An increasing number of owners should also help keep discussions focused on business matters because these owners are not part of the siblings' family history and related tension, animosity, and jealousy (Gordon and Nicholson 2008) and will primarily advance an economic agenda, such as toward achieving growth. Given their formal power, outside owners should also be in the 
position to monitor and sanction siblings' eventual opportunistic behavior and thereby align the siblings behind a jointly developed strategy that seeks to steer the firm toward a higher-growth path (Kale et al. 2000, Penrose 1959). In consequence, a sibling team that runs a firm with an increasing number of owners is thus likely to squander less energy on negative group dynamics (Smith et al. 1994). In summary, we expect that the growth advantage of spousal over sibling teams should weaken with number of owners. We thus posit:

HYPOTHESIS 3 (H3). The number of owners weakens the growth advantage of firms run by spousal teams compared to firms run by sibling teams.

\section{The Moderating Impact of Heterogeneity in Team Industry Experience}

We further argue that heterogeneity in industry experience among team members should strengthen spousal teams' growth advantages but aggravate sibling teams' growth disadvantages. Heterogeneity in industry experience implies that team members have different points of view regarding how to operate the business (Eisenhardt and Bird Schoonhoven 1990). Teams composed of members with heterogeneous industry experience bring together individuals with distinct experiences and resources, reducing the likelihood that ideas, competencies, networks, or resources are redundant (Ruef 2010a). While team members with long experience within a particular industry contribute knowledge of how that industry operates, those with less experience bring a fresh perspective and the freedom to break free of the cognitive constraints of team members with long industry tenure (Eisenhardt and Bird Schoonhoven 1990, Ruef 2010a). When combined inside a team, these different viewpoints typically counteract groupthink or an insufficient airing of alternatives, leading to firm growth (Eisenhardt and Bird Schoonhoven 1990, Ruef 2010a).

We expect that this positive view about heterogeneity in industry experience should be particularly applicable to spousal teams because deep information exchange between spouses in both the private and business spheres provides a context in which different views about growth options are discussed in full. Because team heterogeneity threatens cohesion and often spurs conflict (Smith et al. 1994, Wiersema and Bantel 1992) harnessing the advantages tied to diversity requires the team to be willing to accommodate and constructively engage diverging viewpoints and to consider diversity as a source of enrichment rather than a reason for confrontation. This tolerance for diversity in opinions necessitates a pronounced level of trust and 
the feeling that team members share fundamental values and a vision for the firm despite differences in experience, attributes that are common in spousal teams.

The trusted atmosphere and interdependence among spouses should also limit the threat of opportunistic behavior within the team that could arise due to heterogeneity in team industry experience (Ruef 2010a). For example, opportunistic behavior within teams with diverse experiences could arise when team members with less industry experience free ride on the valued contributions of those with longer industry experience. In consequence, out of fear of such opportunism, those with more experience may withhold such contributions, especially firm-specific contributions, leading to a breakdown of collective action and teamwork (Alchian and Woodward 1988). ${ }^{3}$ Spousal teams should thus possess relational embeddedness attributes that equip them with heightened capabilities to exploit heterogeneity in the team industry experience for growth.

Compared to spouses, siblings should experience more challenges in reaping the rewards tied to heterogeneity in team industry experience. Given lower levels of trust, siblings should be more inclined than spouses to consider diversity in experience and viewpoints as a source of distraction and discount differing viewpoints aired by their brother or sister. Different views about how to grow the firm may even be seen as acts of opposition or outright hostility among siblings, which may escalate latent sibling feuds. Because siblings tend to be more independent than spouses, problems associated with collective action resulting from the varying contributions of team members with heterogeneous industry experience should become more salient for siblings than for spouses (Olson 2009). Moreover, since mutual obligations are less evident among siblings than among spouses (White 2001), siblings should also experience less affective and normative commitments to turn different views into productive outcomes that would fuel firm growth. In sum, if diversity in industry experience occurs in a team with restrained levels of trust, identification, and mutual obligations, the growth potential tied to this diversity is not only likely to be left underexploited but may even lead to an aggravation of the growth disadvantages experienced by this type of team. In summary, we suggest that heterogeneity in team industry experience should strengthen the growth advantage of spousal teams but should worsen the growth disadvantage of sibling teams. Put differently, we expect that the growth advantage of spousal teams over sibling teams should strengthen with heterogeneity in team industry experience. We posit: 
HYPOTHESIS 4 (H4). Heterogeneity in team industry experience strengthens the growth advantage of firms run by spousal teams compared to firms run by sibling teams.

\section{Methods}

\section{Data and Sample}

We investigate our hypotheses on all private Swedish firms with at least five employees that were in existence in the four-year period between 2004 and 2007. Our analysis is based on four longitudinal databases that cover all private companies and individuals in Sweden between 2004 and 2007 and are provided by Statistics Sweden, the official census bureau in Sweden. The first database, RAMS ${ }^{4}$, provides yearly data on all registered firms and also provides firm-level measures, such as number of employees, sales, profitability, and leverage. The second database, LISA ${ }^{5}$, comprises information on all individuals aged 16 or older living in Sweden. The LISA database integrates data from the labor market and from the educational and social security sectors as well as information on employment status. The third database, the Jobbregistret ("work register") provides information on individuals' business activities and corresponding income sources. Fourth, the multigenerational database ${ }^{6}$ provides information on couples as well as on biologically linked families (i.e., parents, children, and siblings). By linking these databases, we were able to identify firms owned and managed by siblings or spouses. Because we are interested in firms run by spousal and sibling teams, we excluded nonfamily firms and other family firms not qualifying as spousal- or sibling-run firms. Through this procedure and by matching spousal teams to sibling teams using propensity score matching (PSM), we identified 4,900 private firms, resulting in 8,162 firm-year observations over the period of 2004 to 2007, for which all required databases were available.

\section{Measures}

The dependent variable was measured at time $t$, and unless stated otherwise, we lagged the independent and control variables at $t-1$ to avoid simultaneity bias.

Dependent variable. Previous studies have measured growth as change in return on assets, profitability, return on equity, return on sales, sales, and employment (Achtenhagen et al. 2010, Delmar 2006, O'Boyle Jr et al. 2012), indicating how heterogeneous the study of firm growth is (Delmar et al. 2003). However, the correlation between these measures tends to be low (Achtenhagen et al. 2010). ${ }^{7}$ Measures related to employees 
and sales are the most common (Delmar et al. 2003). In this study, we measured firm growth as change in number of employees for several reasons (Delmar 2006). First, Penrosean growth theory stipulates that firm growth is primarily associated with the expansion of resources (Peng and Heath 1996), such as the expansion of human resources, which can be operationalized as increase in employees (Achtenhagen et al. 2010, Delmar et al. 2003, Lockett et al. 2011). Second, in contrast to employee growth, sales is sensitive to inflation and currency-exchange rates (Delmar et al. 2003). Third, while sales can occur at different stages of the growth process, change in employees constitutes a more stable growth measure, which indicates a more final and hence more representative adjustment to change (Delmar 2006). Change in employees is thus a more reliable measure in private firms since sales figures tend to fluctuate strongly given the less established customer base. Fourth, Shepherd and Wiklund (2009) found that growth measured as change in employees yielded the most instances of concurrent validity and showed higher robustness than other growth measures.

Thus, we calculated the growth rate for reach firm $i$ in point $t\left(g_{i, t}\right)$ as the logarithmic difference in employees from the previous year (similar to Angelini and Generale 2008, Brush et al. 2000, Colombo and Grilli 2005, Daunfeldt and Halvarsson 2015, Lockett et al. 2011) ${ }^{8}$, which is reflected in following formula:

$$
g_{i, t}=\ln \left[\text { no of employees }_{t}\right]-\ln \left[\text { no of employees } \text { em }_{t-1}\right]^{9}
$$

The logarithm of the growth variable corrects for the skewed distribution, resulting in a normal distribution, which is especially important for relatively short time periods (Delmar 2006). These growth measures were recorded for the period between 2005 and 2007.

Independent variable. Spousal team. The spousal team variable refers to a firm that is owned and managed by a spousal couple. A spousal couple is defined as a couple that is married, has a registered partnership, or lives together with children. In this way, our measure of spousal teams captures the multiple forms of partnerships in Swedish society (Hantrais 2004). The spousal entrepreneur variable takes the value of 1 when both spouses obtained their main income from the firm while also taking an ownership and management position in that firm (Bird and Wennberg 2014, Folta et al. 2010). ${ }^{10}$ Sibling teams served as the reference group and were coded 0 . Sibling teams refer to the situation when at least two siblings obtained their main income from the firm while also taking an ownership and management position in that firm. ${ }^{11}$ 
Moderating variables. Firm age (ln). Firm age was measured as the number of years a firm existed since its inception. The variable was truncated over 20 years because we were only able to determine the exact founding year from 1987 onwards. For firms founded in 1986 or before, the database reports a constant firm age of 21 years, which would have represented a source of bias. We excluded these firms from the main analysis. Since only $5.5 \%$ of the firms in our propensity score-matched sample were older than 20 years, the risk of a systematic bias is small. ${ }^{12} \mathrm{We}$ took the natural logarithm of this variable to correct for its skewness.

Number of owners. We calculated this variable as the total number of owners for each firm in each year.

Heterogeneity in team industry experience. We measured heterogeneity in team industry experience by computing the coefficient of variation for the number of years of industry experience within the entrepreneurial team. The coefficient of variation captures diversity as disparity and is thus preferable over team members' standard deviation in years. ${ }^{13}$ The coefficient of variation is operationalized as the standard deviation of the number of years of industry experience within an entrepreneurial team divided by the team's average number of years of industry experience (Harrison and Klein 2007). Here, years of industry experience denotes the number of years of work experience a team member has gained in the same industry as the firm he or she is currently involved in.

Control variables. Turnover (ln). Firm size is strongly related to firm growth (Delmar et al. 2003), with research postulating that growth rates diminish with increasing size (Sutton 1997). To assess firm size, we computed the natural logarithm of turnover. Altman's Z-score. This variable indicates the financial distress of a company. Firms with lower financial distress have higher growth rates since they have the necessary funds to expand (Almus and Nerlinger 1999). ${ }^{14}$ Return on assets $(\ln )$. Return on assets (ROA) is believed to be a precursor for growth (Angelini and Generale 2008). We took the natural logarithm of this variable to account for skewness. Urban region. It is often assumed that urban areas provide more supportive environments for firm growth than rural areas since resources are more easily accessible for firms (Keeble and Walker 1994), which may have a positive impact on firm growth. ${ }^{15}$ We coded urban regions as 1 "urban municipality" and otherwise set this variable to 0 . Team years of education (mean). This variable represents the general human capital stock available within the entrepreneurial team (Becker 1993) and was measured as the average number of years of education received by entrepreneurial team members. Education has been proven to be positively 
associated with firm growth as education improves entrepreneurs' cognitive abilities to recognize underexploited resources (Colombo and Grilli 2005). Team age (mean). This variable denotes the average age of entrepreneurial team members. Entrepreneurial team structures with a high mean age might be associated with lower growth rates since they tend to employ more conservative strategies (Hambrick and Mason 1984). Full-time owners in percent. The income obtained from the company does not necessarily represent owners' main source of income, which could have an impact on owners' motivations to take risks to grow the firm. Using the LISA database, we divided the number of owners obtaining their main income from the respective firm by the total number of owners. Potential heirs $(\ln )$. The existence of heirs gives the entrepreneurial team an opportunity to ensure transgenerational family control, a strong source of utility and motivation to grow the firm (Zellweger et al. 2012a). Similar to Wiklund et al. (2013), we measured potential heirs as the logarithmized total number of children of all entrepreneurial team members. Proportion of employees with higher education. Employees with higher education embody knowledge and constitute an important resource for the firm (Kogut and Zander 1996, Penrose 1959). Using the LISA database, we calculated this variable by dividing the number of employees with college or university education by the total number of a firm's employees. Industry. To control for industry effects (Audretsch 1995), we employed industry dummies based on the Swedish Industry Classification (SNI) at the one-digit level. We also controlled for the firms that exited our sample and thus controlled for survivor bias $(l a m b d a)$. We applied a generalization of the Heckman selection model to compute a selection variable controlling for firm exit (Lee 1983). Including such a variable allowed us to obtain more precise results as not controlling for this bias leads to omitted variable bias (Greene 2000). We computed the probability of firm exit with Cox proportional hazard models and included a generated sample-correction variable, lambda, into our regression models.

Propensity Score Matching Procedure. We constructed the sample of firms run by sibling and spousal teams using PSM and employed the nearest neighbor technique. ${ }^{16}$ In nearest neighbor matching, each firm in the treatment group (i.e., firms run by spousal teams) is matched with a firm from the control group (i.e., firms run by siblings) that is closest to the treated unit in terms of its propensity score (Li 2012). Following Rosenbaum and Rubin (1983) and Heckman et al. (1998), we used this procedure to control for differences in characteristics between firms run by sibling and spousal teams and to address potential selection bias (i.e., endogeneity). 
To calculate firms' propensity score, we employed two distinct firm characteristics that are expected to influence firms' likelihood of becoming a spousal- or sibling-run firm. Since siblings often have a spouse with income that is diversified away from the firm whereas spouses who are in business together face a highly interdependent and concentrated financial position (Ruef 2010a), the two types of teams may systematically differ in terms of risk propensity as indicated by leverage, which we measured as debt-to-equity ratio, or industry preferences. In regard to industry, we took into account ten industries based on SNI classification. We then stratified the propensity score into different strata and tested the balance for each stratum (using Stata command "pscore"), concluding that the balancing property was satisfied (Li 2012). Finally, we checked whether the covariates used in the PSM were balanced (using Stata command "pstest") and concluded that through the matching procedure, differences in means between the control and treatment group became insignificant and resulted in a bias reduction compared to the unmatched sample. Our final sample consisted of 8,162 firm-year observations. We refer to this as the propensity score-matched sample.

Analytical procedures. We used generalized estimation equation (GEE) regression models as this method assumes independence between our individual observations (i.e., in our case, the firm) and allowed us to fit population-averaged panel data models. Further, these models enable within-group correlations of covariates (Rabe-Hesketh and Skrondal 2012) — a necessary requirement when making inferences about regression coefficients. When specifying our GEE models, we chose an unstructured working correlation matrix since "it is the least restrictive in terms of modeling the true correlation structure within subject" (Ballinger 2004).

\section{Results}

Table 1 displays the descriptive statistics and the correlations, indicating only moderate correlations. Variance inflation factors (VIFs) are all below 2.10, suggesting that multicollinearity is not a major concern in our data.

Insert Table 1 about here

Of the 8,162 observations, 5,418 (66.4\%) firm observations comprised spousal teams, whereas 2,744 (33.6\%) firm observations comprised sibling teams. The average annual growth rate across the three years in terms of percentage change in employees amounts to $5.91 \%$ for sibling entrepreneurs, whereas spousal entrepreneurs achieved a growth rate of $7.65 \%$ during the same period. 
Insert Table 2 about here

Table 2 displays the results of the tested regression models. Model 1 includes all control and independent variables and provides support for Hypothesis 1, which posited that spousal teams have higher firm growth than firms run by sibling teams $(\beta=0.0159, \mathrm{p}<0.01)$. In terms of practical significance, the presence of spousal teams increases firm growth by $1.59 \%$. Model 2 shows the interaction between spousal teams and firm age. We observe a negative and significant effect $(\beta=-0.0126, \mathrm{p}<0.01)$ in support of Hypothesis 2 (see Figure 1). In terms of the marginal effects, holding all other variables constant at their mean values, a one-unit increase in firm age implies a relative decrease in growth by $1.26 \%$ in the presence of spousal teams.

Insert Figure 1 about here

Model 3 shows the interaction effect between spousal teams and number of owners. Hypothesis 3 expected a negative interaction effect between these two variables, which we found no support for ( $\beta=$ $0.0047, \mathrm{p}>0.1$ ). Model 4 shows the interaction between spousal teams and heterogeneity in team industry experience. We observe a positive and significant effect $(\beta=0.0205, \mathrm{p}<0.05)$ in support of Hypothesis 4 (see Figure 2). In terms of the marginal effect, holding all variables constant at their mean values, a one-unit increase in heterogeneity in team industry experience implies a relative increase in growth by $2.05 \%$ in the presence of spousal teams. We also ran a full model including all three interaction terms and found that our results remained similar. Wald chi-square tests confirmed that adding interaction effects from the base model (Model 1) to the next model significantly improves model fit (Model 2, Model 3, Model 4).

Insert Figure 2 about here

\section{Robustness Tests}

We conducted a number of robustness tests to investigate the reliability of our results. First, we investigated the results on the full sample (i.e., without applying the propensity matching procedure) and found that the results remained very similar. Second, we investigated whether our results hold if another family type, such as intergenerational involvement (i.e., a parent with a child), is prevalent among the entrepreneurial group, which therefore served as a reference group in comparison to the spousal and sibling teams respectively. We 
first compared the spousal teams with intergenerational involvement serving as a reference group and found that spousal teams also have a significant growth advantage over teams with intergenerational involvement. In regard to the moderating effects, with increasing firm age, the growth advantage of spousal teams when compared to teams with intergenerational involvement diminishes (at the $0.1 \%$ significance level) while number of owners and heterogeneity in team industry experience reinforce the growth advantage (both moderating effects are at the $10 \%$ significance level). Comparing sibling teams with teams having intergenerational involvement showed that siblings also have a growth disadvantage compared to this kind of entrepreneurial group. When intergenerational teams serve as a reference category to sibling teams, number of owners positively moderates the relationship between firm growth and the prevalence of sibling teams, whereas firm age and heterogeneity in team industry experience have no significant effect, indicating that the relational dynamics differ from those observed for spousal teams.

As another robustness test, we chose to compare spousal teams with teams composed of mixed-sex siblings to investigate whether spousal teams' advantage stems from gender diversity (Milliken and Martins 1996). The results showed that the main effect and the moderating effects become even stronger (with the exception of number of owners, which remains insignificant). In another step, we compared spousal and sibling teams who have been coworkers in a firm other than the one they are currently involved in and found also that the main effect and the moderating effect of firm age became even stronger, whereas number of owners remains insignificant. Further, heterogeneity in team industry experience turns insignificant.

Also, we investigated whether our results remained stable if we employed coworkers (i.e., individuals who previously worked together in another firm but are not bound together by family ties) as a reference group. We observed that spousal teams who have been coworkers before entering the firm have no growth advantage over coworkers without family ties (i.e., insignificant relationship). When comparing sibling teams who have been coworkers in another firm to coworkers without family ties, we observe that sibling teams have a growth disadvantage compared to coworkers and that they display the same patterns with regard to moderating effects as when compared to the spousal teams in the main analysis of this paper.

As an additional robustness test, we also included firm age in the PSM model and observed that the results in the main models remain stable. We do not rely on this propensity score-matched sample to avoid over- 
parameterization as including firm age could have made the common support assumption too difficult to fulfill (Lechner 2010). Moreover, we tested whether outliers affect the results. We removed the top and bottom 5\% of the sample and re-ran the models. We also ran the models using random effects models (which assume the main independent variables are constant over time, as in our case). The results remained consistent. We also checked whether our results would hold if we ran ordinary least squares regressions and found that our results remained very similar. In addition, we checked whether our results remained consistent if we included partners and siblings who are only part-time team members as independent variables. Including this wider definition of spousal and sibling teams did not alter our results. Additionally, we checked if our results would hold if we also included firms older than 20 years of age and found that our results remained the same. Also, we also re-ran our analysis using sales growth as the dependent variable, which was computed similar to the growth variable used in our main analysis (Batt 2002, Brush et al. 2000). Our results showed that although spousal teams have a positive effect on sales growth, that effect is not statistically significant $(\mathrm{p}<0.17)$, indicating that growth in employees is a different growth measure than sales growth. Finally, we checked whether our results hold if we investigated firm shutdown as the dependent variable using competing risks regressions (coded 0 if the firm survived; 1 if the firm was shut down; and 2 if the firm was sold to an external party, which constitutes the competing risk). We found that spousal teams have a lower likelihood of being shut down (at the $10 \%$ significance level) compared to sibling teams when accounting for the competing risk of the firm being sold to an external party. Moderating effects point in the same direction as in the main analysis but are not significant.

\section{Discussion}

Integrating arguments from the social embeddedness perspective of entrepreneurship (e.g., Aldrich and Cliff 2003, Blatt 2009, Ruef 2010b) with Penrosean growth theory (Eisenhardt and Bird Schoonhoven 1990, Lockett et al. 2011, Penrose 1959), we explored how the relational embeddedness of spousal teams and sibling teams impact private firm growth. Theorizing about the higher levels of trust, identification, and obligations in spousal teams compared to sibling teams and probing a sample of all private firms in Sweden over a three-year period, our study revealed that firms run by spousal teams exhibit higher firm growth than firms run by sibling teams. We explored boundary conditions to this baseline relationship and found that firm age weakens and 
heterogeneity in team industry experience intensifies the growth advantage of spousal teams over sibling teams, whereas the number of owners has no significant effect on firm growth.

\section{Contributions to the Theory of Firm Growth}

Our paper proposes a relational embeddedness perspective of firm growth, which expands current conceptualizations of the growth phenomenon (for overviews refer to Davidsson et al. 2010, Wiklund et al. 2009). Studies investigating the relationship between network ties and firm growth have primarily employed structural embeddedness arguments (Nahapiet and Ghoshal 1998) to explain how social networks (Batjargal et al. 2013, Galaskiewicz et al. 2006, Stam and Elfring 2008) and interorganizational alliances (Davidsson et al. 2010, Peng et al. 2008, Stuart 2000) contribute to firm growth. Although there is research investigating how characteristics of the founding team, such as joint work experience and interpersonal trust, influence firm growth (Eisenhardt and Bird Schoonhoven 1990), we put forth arguments about how an entrepreneurial team's relational embeddedness - namely, firm resources created and leveraged through relationships within the team (Nahapiet and Ghoshal 1998, p. 244)—impact firm growth. By systematizing the importance of teams' relationships, we contribute to a relationally contingent understanding of firm growth and provide a theoretically grounded link between two highly influential but largely disconnected streams of literature.

Even though Penrose (1959) implicitly recognized the importance of relational aspects of managerial collaboration for growth, she applied a somewhat simplified view of cooperation. For instance, she assumed that entrepreneurs' knowledge of each other should facilitate growth. However, as we have shown for spousal and sibling teams, the mere fact that entrepreneurs know each other is insufficient to explain variance in firm growth. Without trust, shared identity, and mutual obligations of support, team members' knowledge of each other can also be used in ways that are destructive for growth, for instance, through conflicts and opportunistic behavior, which are more likely to be experienced among sibling teams than among spousal teams. Thus, it is not merely sheer experience and knowledge of each other that matter for growth, as argued by Penrose, but the relational embeddedness and hence the levels of trust, identification, and obligations among those at the helm of the firm (Blatt 2009, Moran 2005, Nahapiet and Ghoshal 1998).

\section{Contributions to the Theory of Social Embeddedness of Organizations}


A key contribution of the social embeddedness theory of firms is that it takes organizations' pursuit of economic activity seriously while simultaneously acknowledging that such activity is centrally, not peripherally, embedded in ongoing patterns of social relations (Granovetter 1985, Portes and Sensenbrenner 1993, Uzzi 1997). Researchers have faced conceptual and empirical challenges in mapping the ideational core of embeddedness and its effect on "economic action," particularly for audiences outside the direct realm of economic sociology (Dacin et al. 1999). A possible reason for why management scholars have not engaged the social embeddedness theory of the firm more is some vagueness about the meaning of the term "economic action," which should be affected by social embeddedness (Beckert 2003, Granovetter 1985). In his foundational study, Uzzi (1996) used firm survival as a proxy for economic action, whereas others have looked into intermediary outcomes, such as managerial performance (Moran 2005) or product innovation (Tsai and Ghoshal 1998). We chose firm growth as our focal variable and thus tested our theorizing on a construct that is of central concern to researchers and practitioners alike.

\section{Contributions to the Family Embeddedness Literature}

We also contribute to the burgeoning literature on family embeddedness (Aldrich and Cliff 2003, Le Breton-Miller and Miller 2009, Yang and Aldrich 2014). In their foundational article, Aldrich and Cliff (2003, p. 574) proposed a family embeddedness view of new venture creation emphasizing the "entrepreneur's family system," defined as the "transitions, resources, and norms, attitudes and values" that can influence launch decisions, resource mobilization, survival, and objective and subjective performance. We expand family embeddedness arguments by highlighting the family's influence on entrepreneurial outcomes beyond the founding context to more established firms and by showing that relational embeddedness in family ties is an essential aspect of family embeddedness. Our article thus shows that family relationships, and hence the family in itself, are perhaps the ultimate firm resource — not the physical, social, or financial capital that families provide (Sirmon and Hitt 2003) — and that these relationships have a critical impact on firm growth. From this extension, we learn how important it is to distinguish between various types of family teams (Parsons 1949), such as sibling and spousal teams, because such teams vary in levels trust, identification, and mutual obligations, all of which impact firm growth. With this in mind, it is unsatisfactory to equate family 
embeddedness with the degree of family involvement (Le Breton-Miller and Miller 2009) or to lump all families with biological linkages together (e.g., sibling teams and parent/children teams) (Brannon et al. 2013).

\section{Contributions to the Entrepreneurship Literature}

We contribute to the entrepreneurship literature by highlighting heterogeneity within the family as an entrepreneurial group (Ruef 2010a). The literature on entrepreneurial teams has argued that individuals tend to group with other individuals based on familiarity (Ruef 2010a). We show that familiarity among team members may be sufficient to form an entrepreneurial team (Ruef et al. 2003) but ultimately insufficient to drive firm growth as even within one of the most intimate types of teams - the family — relationship quality may differ. This finding directly speaks to the entrepreneurial growth literature (Audretsch et al. 2014, Wright and Stigliani 2012), indicating that various family relationships have disparate effects on entrepreneurial teams' ability to grow a firm and that close, intimate ties, such as between spouses, are positive for growth.

Finding that teams with close, intimate ties are beneficial for growth (e.g., in the case of spouses, especially when the firm is young or the spouses exhibit heterogeneous industry experience) is important and novel because past studies have emphasized the constraints imposed by "over-embedded" ties, arguing that such ties prevent firms from accessing novel information, which could have negative consequences for innovation (Belenzon et al. 2015, Granovetter 1973, Le Breton-Miller et al. 2011, Ruef 2002). Our results are intriguing since they suggest that teams experiencing structural embeddedness constraints in line with the strength of weak ties hypothesis ${ }^{17}$ (Granovetter 1973) may excel in terms of relational embeddedness, which leads to advantages in firm growth.

Our findings regarding the moderating impact of firm age and heterogeneity in industry experience within the team also demonstrate the importance of family team dynamics for firm growth. In particular, we show that the relational embeddedness advantages of spouses that are particularly valuable in the founding stage become less valuable as firms mature. Further, spouses' relational embeddedness constitutes a major asset in terms of leveraging heterogeneous industry experience, as it enables spouses to avoid conflict and exploit divergent viewpoints more successfully. More generally, by further clarifying the role of the family in entrepreneurship, we contribute to a burgeoning kinship perspective of entrepreneurship (Verver and Koning 2017, Zellweger et al. 2012b). Interestingly, our results remained stable when we compared spousal team with mixed-gender 
sibling teams, indicating that the spousal advantage does not stem from a possible gender-diversity effect (Yang and Aldrich 2014). Also, building on Ruef (2010a) and insights from prior growth literature (Eisenhardt and Bird Schoonhoven 1990), we provide a more nuanced view by comparing spousal teams who have been coworkers with sibling teams who have been coworkers in another company. Again, our results remained robust, indicating that sibling teams cannot overcome their relational disadvantages even when having worked together previously.

Our non-finding for number of owners warrants further discussion. Apparently, the impact of spouses' relational embeddedness on firm growth is unaffected by the number of owners - at least when compared to siblings. The spousal bond and the associated relational attributes may be sufficiently strong to counter the dilution of a joint vision and the shared motivation to grow a firm even though third parties are invested in the firm. This finding has practical implications since it suggests that outside owners who invest in firms run by spouses may have limited influence to alter those firms' growth path.

\section{Contributions to the Family Business Literature}

There is an abundant stream of research on the financial performance of family firms (Amit and Villalonga 2013, Miller et al. 2007). However, hitherto, we knew very little about the circumstances surrounding family firm growth (Lee 2006). Our paper suggests that we can better understand heterogeneity in family firm growth by accounting for heterogeneity in entrepreneurial family teams (Chua et al. 2012). Our findings suggest that family business research may have adopted a rather simplistic, often too rosy view of familial relationships, generally describing such relationships as being based on benevolence, trust, and altruism. More specifically, our work makes family business researchers and practitioners aware of the need to more closely distinguish between family types in their work (Parsons 1949).

\section{Limitations}

Given limitations in our secondary database, our sample does not include precise firm age data for firms older than 20 years, so all firms older than 20 years are classified as 21 years old (5.5\% of firms in the propensity score-matched sample are classified as 21 years old). However, our robustness test showed that including firms that were classified as 21 years of age did not alter our results. This limitation in our data is unfortunate but needs to be weighed against the opportunity to explore all private firms from a single country 
over multiple years and matching firm-level data with fine-grained individual-level and family-level data. In addition, we measured relational embeddedness indirectly by capturing whether a firm was controlled by spouses or by siblings. However, such proximal measures are not uncommon in management (Fama and Jensen 1983, Gómez-Mejía et al. 2010) and relational embeddedness research (Barden and Mitchell 2007). Also, we took a rather static view of family structures. Family types in the 21 st century reflect a changing and wide-ranging notion of the family, including a mix of household forms, such as multiple unrelated people living under the same roof (Aldrich and Cliff 2003). Still, our measure for spousal couples captures the most prominent types of spousal partnerships.

\section{Opportunities for Future Research}

In light of previous research documenting the structural constraints associated with family ties, particularly information redundancy (Granovetter 1973, Ruef 2010a), investigating the interplay between relational and structural embeddedness seems to be a promising new path for future research. In exploring the links between structural and relational embeddedness, it seems important to systematize the link between embeddedness and various forms of economic action. This endeavor is valuable since structural constraints, such as those observed for strong ties between spouses, may indeed limit innovation (Ruef 2010a). However, the same type of team can exhibit relational advantages that prove to be beneficial for other types of economic action, such as firm growth. Future research could thus ask how the interplay between entrepreneurial teams' structural and relational embeddedness impact various types of firm-level economic outcomes.

We see our study as a stepping stone to further explorations of the economic consequences of having various family types at the helms of firms (e.g., extended family, intergenerational involvement; see also the seven family types outlined by Parsons [1949]). Such research endeavors may take into account distribution of power (Parsons 1949, Yang and Aldrich 2014), relational dynamics (Gurman and Kniskern 2013), and life course events as well as changing family composition patterns (Elder 1998) within entrepreneurial families. It would also be fascinating to study how various family transitions, such as divorce, marriage, and childbirth, influence relational dynamics within the entrepreneurial team and how these transitions influence firm outcomes, such as firm growth. In these attempts to further unpack family effects, work on family sociology (Chambers 2015, Parsons 1949) and family theory (Bengtson et al. 2005, Smith et al. 2008) should prove to be 
helpful. Departing from our work, it also seems promising to explore different forms of spousal relationships (e.g., married versus cohabiting spousal relationships) in greater detail (Hantrais 2004). Future research could also study sibling constellations further, such as birth order, gender, and age spacing (Furman and Buhrmester 1985) as well as the impact of in-laws and parents' departure from the firm on an entrepreneurial team's relational embeddedness, particularly when the parents are the founders (Villalonga and Amit 2006).

Our paper also calls for more foundational work on the elusive role of family in entrepreneurship. Family embeddedness writings have tentatively pointed to the importance of families for the creation of new firms and the changing nature of family composition in the 21 st century, which should alter the ways families impact new firm creation (Aldrich and Cliff 2003, Aldrich and Kim 2007, Ruef et al. 2003, Zellweger 2017). Despite the undisputed merit of these works, we still lack a more systematic and integrative understanding of the ways families contribute to the creation of new firms (Bird and Wennberg 2014, Verver and Koning 2017), the innovative behavior (Kammerlander et al. 2015) and survival of existing firms (Jaskiewicz et al. 2015), just as the cultivation of transgenerational entrepreneurship (Zellweger et al. 2012b).

It will be interesting to see how much our deliberations about trust, identification, and obligations also apply to non-family entrepreneurial teams, such as former co-workers, friends, or fellow students. Additionally, future research may explore how relational embeddedness will impact various team dynamics, such as entrepreneurial team formation or team dissolution (Francis and Sandberg 2000, Ruef et al. 2003). Moreover, it appears promising to explore the social and industrial contexts in which relational embeddedness is particularly valuable (Welter 2011). For instance, one may speculate that under high levels of uncertainty or in the absence of strong formal institutions, relational embeddedness should be particularly valuable for firm prosperity (Miller et al. 2009). Future research could also benefit from applying and refining scales that would enable the direct measurement of trust, identification, and obligations (Kale et al. 2000, Moran 2005). In sum, we see a multitude of research streams that could build on our relational embeddedness perspective of organizational outcomes.

\section{Conclusion}

Our paper provides a fresh perspective to explain why private firms grow and how this growth can be attributed to the relationships within the family team at the helm of the firm. In fact, we showed that 
entrepreneurial teams composed of different family types have the potential to either constrain or foster firm

growth. We conclude that the embeddedness perspective holds wide promise in describing organizational

outcomes, and we hope that our paper will stimulate numerous conversations within the management, family

business, and entrepreneurship fields that will challenge, replicate, and extend our findings.

\section{Endnotes}

${ }^{1}$ Because divorce constitutes a potential threat to spouses' relational embeddedness, we explored how many spousal teams went through a divorce in the period investigated. We found that only $7.09 \%$ of the firms in our sample experienced such an event, concluding that divorce is less likely to happen among spousal teams compared to the general population.

2 There is only limited data on the prevalence of sibling teams in business. Ruef (2010a) estimated that about $15 \%$ of owner teams in the United States rely on non-spousal kinship ties, which includes both consanguineous relationships (typically siblings) and affinity-based relationships. About $15 \%$ are teams with coworkers, while those with friends or acquaintances are slightly more common at about $20 \%$.

${ }^{3}$ The opposite scenario is also conceivable: The less experienced party withholds novel input out of fear of being held up, while the more experienced party freerides on the novelty and freshness of the perspectives given by the less experienced team member.

${ }^{4}$ RAMS is the Swedish acronym for "Registerbaserad arbetsmarknadsstatistik."

${ }^{5}$ LISA is the Swedish acronym for "Longitudinell integrationsdatabas för Sjukförsäkrings-och Arbetsmarknadsstudier."

${ }^{6}$ In Swedish, "flergenerationsregistret." Couples are defined as individuals who are married, have a registered partnership, or are cohabiting with children.

${ }^{7}$ Modest correlations were found between absolute growth in employees and absolute sales growth, between absolute growth in employees and employees' growth rate, as well as between return on equity and return on assets (Achtenhagen et al. 2010).

${ }^{8}$ This procedure follows the calculation of logarithmic returns, which constitutes the log difference of firms' employees at the measured yearly interval and assumes that the growth rate is consistent over time (and is therefore time additive).

${ }^{9}$ Please note that this is equivalent to the following:

$g_{i, t}=\ln \left[\frac{\text { no of employees }}{t}\right]$

${ }^{10}$ Thus, we defined the spousal team variable as the situation when both spouses are classified as "entrepreneur" by Statistics Sweden and thus obtained their main income from the firm while also taking an ownership position in that firm.

${ }^{11}$ We excluded firms including both family constellations (i.e., siblings and spousal teams were present within one firm).

${ }^{12}$ In the robustness test section, we also included those firms (older than 20 years) in our sample. Our results remained consistent.

13 "Disparity reflects both the distances between unit members and the dominance of (concentration of the resources in) those who have higher amounts of an attribute" - in this case, the number of years of industry experience (Harrison and Klein 2007, p. 1212).

${ }^{14}$ We employed the following formula: $\mathrm{A} * 3.3+\mathrm{B} * 0.99+\mathrm{C} * 0.6+\mathrm{D} * 1.2+\mathrm{E} * 1.4$, where $\mathrm{A}=\mathrm{EBIT} /$ total assets (measures the productivity of firm assets), $\mathrm{B}=$ sales / total assets (the sales generating ability of firm assets), $\mathrm{C}=$ book value of equity / total liabilities (measures potential for insolvency), $\mathrm{D}=$ working capital $/$ total assets (measures net liquid assets relative to total capitalization), and $\mathrm{E}=$ retained earnings / total assets (measures amount of reinvested earnings and/or losses in the firm).

${ }^{15}$ We classified regions as urban according to a classification provided by Statistics Sweden comprising nine categories of urbanization. For instance, 1 is "urban municipality," 2 is "suburban municipality," 7 is "rural municipality," 8 is "sparsely populated municipality," and 9 is "other small municipality."

${ }^{16}$ PSM was conducted "with replacement" following Morgan and Harding (2006), who found that this approach is superior to matching without replacement (see also, Roberts and Whited 2012).

17 Strong ties often carry the cost of information redundancies while weak ties can provide novel and non-redundant information (Granovetter 1973). 


\section{References}

Achtenhagen L, Naldi L, Melin L (2010) "Business Growth" - Do practitioners and scholars really talk about the same thing. Entrepreneurship Theory and Practice 34(2): 289-316.

Adler PS, Kwon S-W (2002) Social capital: Prospects for a new concept. Academy of Management Review 27(1): 17-40.

Alchian AA, Woodward S (1988) Review: The firm is dead; Long live the firm a review of Oliver E. Williamson's the economic institutions of capitalism. Journal of Economic Literature 26(1): 65-79.

Aldrich HE, Cliff JE (2003) The pervasive effects of family on entrepreneurship: Toward a family embeddedness perspective. Journal of Business Venturing 18(5): 573-596.

Aldrich HE, Kim PH (2007) A life course perspective on occupational inheritance: Self-employed parents and their children. Ruef M, Lounsbury M, eds. Research in the Sociology of Organizations (Elsevier JAI Press: Amsterdam), 33-82.

Almus M, Nerlinger EA (1999) Growth of new technology-based firms: Which factors matter? Small Business Economics 13(2): 141-154.

Amit R, Villalonga B (2013) Financial performance of family firms. Melin L, Nordqvist M, Sharma P, eds. The SAGE Handbook of Family Business (SAGE Publications, London, UK), 157-178.

Angelini P, Generale A (2008) On the evolution of firm size distributions. American Economic Review 98(1): 426-438.

Arregle J-L, Hitt MA, Sirmon DG, Very P (2007) The development of organizational social capital: Attributes of family firms. Journal of Management Studies 44(1): 73-95.

Ashforth BE, Mael F (1989) Social identity theory and the organization. Academy of Management Review 14(1): 20-39

Audretsch DB (1995) Innovation and Industry Evolution (MIT Press, Cambridge, US).

Audretsch DB, Coad A, Segarra A (2014) Firm growth and innovation. Small Business Economics 43(4): 743 749.

Ballinger GA (2004) Using generalized estimating equations for longitudinal data analysis. Organizational Research Methods 7(2): 127-150.

Barden JQ, Mitchell W (2007) Disentangling the influences of leaders' relational embeddedness on interorganizational exchange. Academy of Management Journal 50(6): 1440-1461.

Barney J (1991) Firm resources and sustained competitive advantage. Journal of Management 17(1): 99-120.

Barney J, Wright M, Ketchen DJ (2001) The resource-based view of the firm: Ten years after 1991. Journal of Management 27(6): 625-641.

Baron JN, Hannan MT, Burton MD (1999) Building the iron cage: Determinants of managerial intensity in the early years of organizations. American Sociological Review 64(4): 527-547

Batjargal B, Hitt MA, Tsui AS, Arregle J-L, Webb JW, Miller TL (2013) Institutional polycentrism, entrepreneurs' social networks, and new venture growth. Academy of Management Journal 56(4): 1024 1049.

Batt R (2002) Managing customer services: Human resources practices, quit rates, and sales growth. Academy of Management Journal 45(3): 587-597.

Baum RJ, Locke EA, Smith KG (2001) A multidimensional model of venture growth. Academy of Management Journal 44(2): 292-303

Becker GS (1973) A theory of marriage: Part I. Journal of Political Economy 81(4): 813-846.

Becker GS (1993) Human Capital: A Theoretical and Empirical Analysis, with Special Reference to Education, 3rd ed (University of Chicago Press, Chicago, US).

Beckert J (2003) Economic sociology and embeddedness: How shall we conceptualize economic action? Journal of Economic Issues 37(3): 769-787.

Belenzon S, Patacconi A, Zarutskie R (2015) Married to the firm? A large scale investigation of the social context of ownership. Strategic Management Journal 37(13): 2611-2638.

Ben-Porath Y (1980) The F-connection: Families, friends, and firms and the organization of exchange. Population and Development Review 6(1): 1-30.

Bengtson VL, Acock AC, Allen AR, Dilworth- Anderson P, Klein DM (2005) Sourcebook of Family Theory and Research (Sage Publications Thousand Oaks, US). 
Bird M, Wennberg K (2014) Regional influences on the prevalence of family versus non-family start-ups. Journal of Business Venturing 29(3): 421-436.

Bird M, Wennberg K (2016) Why family matters: The impact of family resources on immigrant entrepreneurs' exit from entrepreneurship. Journal of Business Venturing 31(6): 687-704.

Blatt R (2009) Though love: how communal schemas and contracting practices build relational capital in entrepreneurial teams. Academy of Management Review 34(3): 533-551.

Bolino M, Turnley WH, Bloodgood JM (2002) Citizenship behavior and the creation of social capital in organizations. Academy of Management Review 27(4): 505-522.

Bradley SW, Wiklund J, Shepherd DA (2011) Swinging a double-edged sword: The effect of slack on entrepreneurial management and growth. Journal of Business Venturing 26(5): 537-554.

Brannon DL, Wiklund J, Haynie MJ (2013) The varying effects of family relationships in entrepreneurial teams. Entrepreneurship Theory and Practice 37(1): 107-132.

Brody GH (1998) Sibling relationship quality: Its causes and consequences. Annual Review of Psychology 49(1): 1-24.

Brüderl J, Preisendörfer P (1998) Network support and the success of newly founded businesses. Small Business Economics 10(3): 213-225.

Brush TH, Bromiley P, Hendrickx M (2000) The free cash flow hypothesis for sales growth and firm performance. Strategic Management Journal 21(4): 455-472.

Buchanan D, Badham R (2008) Power, politics, and organizational change: Winning the turf game (Sage Publications, London, UK).

Chambers D (2015) A Sociology of Family Life: Change and Diversity in Intimate Relations (Polity Press, Cambridge, UK).

Chua JH, Chrisman JJ, Steier LP, Rau SB (2012) Sources of heterogeneity in family firms: An introduction. Entrepreneurship Theory and Practice 36(6): 1103-1113.

Coleman JS (1990) Foundations of Social Theory (Belknap Press of Harvard University Press, Cambridge, US).

Colombo MG, Grilli L (2005) Founders' human capital and the growth of new technology-based firms: A competence-based view. Research Policy 34(6): 795-816.

Cooper RG, Gimeno-Gascon FJ, Woo CY (1994) Initial human and financial capital as predictors of new venture performance. Journal of Business Venturing 9(5): 371-395.

Dacin MT, Ventresca MJ, Beal BD (1999) The embeddedness of organizations: Dialogue \& directions. Journal of Management 25(3): 317-356.

Danes SM, Morgan EA (2004) Family Business-owning couples: An EFT view into their unique conflict culture. Contemporary Family Therapy 26(3): 241-260.

Daunfeldt S-O, Halvarsson D (2015) Are high-growth firms one-hit wonders? Evidence from Sweden. Small Business Economics 44(2): 361-383.

Davidoff L (2006) The sibling relationship and sibling incest in historical context. Coles P, ed. Sibling Relationships (Karnac Ltd., London, UK), 17-48.

Davidsson P, Achtenhagen E, Naldi L (2010) Small firm growth. Foundations and Trends in Entrepreneurship 6(2): 69-166.

Davidsson P, Delmar F, Wiklund J (2006) Entrepreneurship and the Growth of Firms (Edward Elgar, Cheltenham \& Northampton, UK).

Delmar F (2006) Measuring growth: Methodological considerations and empirical results. Davidsson P, Wiklund J, Delmar F, eds. Entrepreneurship and the Growth of Firms (Edward Elgar, Cheltenham, UK), 62-84.

Delmar F, Davidsson P, Gartner WB (2003) Arriving at the high-growth firm. Journal of Business Venturing 18(2): 189-216.

Delmar F, Wiklund J (2008) The effect of small business managers' growth motivation on firm growth: A longitudinal study. Entrepreneurship Theory and Practice 32(3): 437-457.

Dutton JE, Dukerich JM, Harquail CV (1994) Organizational images and member identification. Administrative Science Quarterly 39(2): 239-263.

Dyer JH, Chu W (2012) The role of trustworthiness in reducing transaction costs and improving performance: Empirical evidence from the United States, Japan, and Korea. Organization Science 14(1): 57-68. 
Ebben J, Johnson A (2006) Bootstrapping in small firms: An empirical analysis of change over time. Journal of Business Venturing 21(6): 851-865.

Eisenhardt KM, Bird Schoonhoven C (1990) Organizational Growth: Linking founding team, strategy, environment, and growth among U.S. semiconductor ventures, 1978-1988. Administrative Science Quarterly 35(3): 504-529.

Elder GH (1998) The life course as developmental theory. Child Development 69(1): 1-12.

Ensley MD, Pearson AW, Amason AC (2002) Understanding the dynamics of new venture top management teams: Cohesion, conflict and new venture performance. Journal of Business Venturing 17(4): 365-386.

Fama EF, Jensen MC (1983) Separation of ownership and control. Journal of Law and Economics 26(2): 301325.

Folta TB, Delmar F, Wennberg K (2010) Hybrid entrepreneurship. Management Science 56(2): 253-269.

Francis DH, Sandberg WR (2000) Friendship within entrepreneurial teams and its association with team and venture performance. Entrepreneurship Theory and Practice 25(2): 5-25.

Furman W, Buhrmester D (1985) Children's perceptions of the personal relationships in their social networks. Developmental Psychology 21(6): 1016-1024.

Galaskiewicz J, Bielefeld W, Dowell M (2006) Networks and organizational growth: A study of community based nonprofits. Administrative Science Quarterly 51(3): 337-380.

Garnsey E (2002) The growth of new ventures: Analysis after Penrose. Pitelis C, ed. The Growth of the Firm: The Legacy of Edith Penrose (Oxford University Press, Oxford, UK), 101-125.

Gilbert BA, McDougall PP, Audretsch DB (2006) New venture growth: A review and extension. Journal of Management 32(6): 926-950.

Gómez-Mejía LR, Makri M, Larraza-Kintana M (2010) Diversification decisions in family-controlled firms. Journal of Management Studies 47(2): 223-252.

Gordon G, Nicholson N (2008) Family Wars: Classic Conflicts in Family Business and How to Deal with Them (Kogan Page Publishers, London, UK).

Granovetter MS (1973) The strength of weak ties. American Journal of Sociology 78(6): 1360-1380.

Granovetter MS (1985) Economic action and social structure: The problem of embeddedness. American Journal of Sociology 91(3): 481-510.

Granovetter MS (1992) Problems of explanation in economic sociology. Nohria N, Eccles R, eds. Networks and Organizations: Structure, Form, and Action (Harvard Business School Press, Boston, US), 25-56.

Grant AM, Asforth SJ (2008) The dynamics of proactivity at work. Research in Organizational Behavior 28: 3-34.

Greene PG, Brown TE (1997) Resource needs and the dynamic capitalism typology. Journal of Business Venturing 12(3): 161-173.

Greene W (2000) Econometric Analysis (Prentice Hall, Upper Saddle River, US).

Greve HR (2008) A behavioral theory of firm growth: Sequential attention to size and performance goals. Academy of Management Journal 51(3): 476-494.

Gurman AS, Kniskern DP (2013) Handbook of Family Therapy (Routledge, London, UK).

Hambrick DC, Mason PA (1984) Upper echelons: The organization as a reflection of its top managers. Academy of Management Review 9(2): 193-206.

Hantrais L (2004) Family Policy Matters-Responding to Family Change in Europe (The Policy Press, Bristol, UK).

Harrison DA, Klein KJ (2007) What's the difference? Diversity constructs as separation, variety, or disparity in organizations. Academy of Management Review 32(4): 1199-1228.

Heckman J, Ichimura H, Todd P (1998) Matching as an econometric evaluation estimator. Review of Economic Studies 65(2): 261-294.

Jaskiewicz P, Combs JG, Rau SB (2015) Entrepreneurial legacy: Toward a theory of how some family firms nurture transgenerational entrepreneurship. Journal of Business Venturing 30(1): 29-49.

Jennings J, Breitkreuz RS, James AE (2014) Theories from family science: A review and roadmap for family business research. Melin L, Nordqvist M, Sharma P, eds. The SAGE Handbook of Family Business (Sage Publications, London, UK), 25-46.

Kale P, Singh H, Perlmutter H (2000) Learning and protection of proprietary assets in strategic alliances: Building relational capital. Strategic Management Journal 21(3): 217-237. 
Kammerlander N, Dessi C, Bird M, Floris M (2015) The Impact of shared stories on family firm innovation: A multicase study. Family Business Review 28(4): 332-354.

Keeble D, Walker S (1994) New firms, small firms and dead firms: Spatial patterns and determinants in the United Kingdom. Regional Studies 28(4): 411-427.

Ketokivi K (2012) The Intimate couple, family and the relational organization of close relationships. Sociology 46(3): 473-489.

Knez M, Camerer C (1994) Creating expectational assets in the laboratory: Coordination in 'weakest-link' games. Strategic Management Journal 15: 101-119.

Kogut B, Zander U (1996) What firms do? Coordination, identity, and learning. Organization Science 7(5): 502-518.

Kor YY, Mahoney JT (2004) Edith Penrose's (1959) contributions to the resource-based view of strategic management. Journal of Management Studies 41(1): 183-191.

Kor YY, Mahoney JT, Michael SC (2007) Resources, capabilities and entrepreneurial perceptions. Journal of Management Studies 44(7): 1187-1212.

Le Breton-Miller I, Miller D (2009) Agency vs. stewardship in public family firms: A social embeddedness reconciliation. Entrepreneurship Theory and Practice 33(6): 1169-1191.

Le Breton-Miller I, Miller D, Lester RH (2011) Stewardship or agency? A social embeddedness reconciliation of conduct and performance in public family businesses. Organization Science 22(3): 704-721.

Lechner M (2010) The Estimation of causal effects by difference-in-difference methods. Foundations and Trends in Econometrics 4(3): 165-224.

Lee J (2006) Family firm performance: Further evidence. Family Business Review 19(2): 103-114.

Lee L (1983) Generalized econometric models with selectivity. Econometrica 51(2): 507-512.

Li M (2012) Using the propensity score method to estimate causal effects: A review and practical guide. Organizational Research Methods 16(2): 1-39.

Lockett A, Wiklund J, Davidsson P, Girma S (2011) Organic and acquisitive growth: Re-examining, testing and extending Penrose's growth theory. Journal of Management Studies 48(1): 48-74.

Matzek AE, Gudmunson CG, Danes SM (2010) Spousal capital as a resource for couples starting a business. Family Relations 59(1): 60-73.

McGrath RG, MacMillan IC, Venkataraman S (1995) Defining and developing competence: A strategic process paradigm. Strategic Management Journal 16(4): 251-275.

McHale SM, Updegraff KA, Whiteman SD (2012) Sibling relationships and influences in childhood and adolescence. Journal of Marriage and Family 74(5): 913-930.

Miller D, Breton-Miller I, Lester RH (2011) Family and lone founder ownership and strategic behaviour: Social context, identity, and institutional logics. Journal of Management Studies 48(1): 1-25.

Miller D, Le Breton-Miller I, Lester RH, Cannella Jr AA (2007) Are family firms really superior performers? Journal of Corporate Finance 13(5): 829-858.

Miller D, Lee J, Chang S, Le Breton-Miller I (2009) Filling the institutional void: The social behavior and performance of family vs non-family technology firms in emerging markets. Journal of International Business Studies 40(5): 802-817.

Milliken FJ, Martins LL (1996) Searching for common threads: Understanding the multiple effects of diversity in organizational groups. Academy of Mangement Review 21(2): 402-433.

Moody J, White D (2003) Structural cohesion and embeddedness: A hierarchical concept of social groups. American Sociological Review 68(1): 103-127.

Moran P (2005) Structural vs. relational embeddedness: Social capital and managerial performance. Strategic Management Journal 26(12): 1129-1151.

Morgan L, Harding DJ (2006) Matching estimators of causal effects: Prospects and pitfalls in the theory and practice. Sociological Methods and Research 16(2): 1-39.

Muske G, Fitzgerald MA, Haynes G, Black M, Chin L, MacClure R, Mashburn A (2009) The intermingling of family and business financial resources: Understanding the copreneurial couple. Journal of Financial Counseling and Planning 20(2): 27-47.

Nahapiet J, Ghoshal S (1998) Social capital, intellectual capital, and the organizational advantage. Academy of Management Review 23(2): 242-266.

Nock SL (1998) Marriage in Men's Live (Oxford University Press, Oxford, UK). 
O'Boyle Jr EH, Pollack JM, Rutherford MW (2012) Exploring the relation between family involvement and firms' financial performance: A meta-analysis of main and moderator effects. Journal of Business Venturing 27(1): $1-18$.

Olson M (2009) The Logic of Collective Action: Public Goods and the Theory of Groups (Harvard University Press, Cambridge, US).

Parsons T (1949) The social structure of the family. Anshen R, ed. The Family: Its Function and Destiny (Harper \& Brothers, New York, US), 241-274.

Peng MW, Heath SP (1996) The growth of the firm in planned economies in transition: Institutions, organizations, and strategic choice. The Academy of Management Review 21(2): 492-528.

Peng MW, Wang DY, Jiang Y (2008) An institution-based view of international business strategy: A focus on emerging economies. Journal of International Business Studies 39(5): 920-936.

Penrose E (1952) Biological analogies in theory of the firm. The American Economic Review 42(5): 804-819.

Penrose E (1955) Research on the business firm: Limits to the growth and size of firms The American Economic Review 45(2): 531-543.

Penrose E (1959) The Theory of Growth of the Firm (Blackwell, Oxford, UK).

Pollak AR (2003) Gary Becker's contributions to family and household economics. Review of Economics of the Household 1(1-2): 111-141.

Portes A, Sensenbrenner J (1993) Embeddedness and immigration: Notes on the social determinants of economic action. The American Journal of Sociology 98(6): 1320-1350.

Powell WW, Smith-Doerr L (1994) Networks and economic life. Smelser NJ, Swedberg R, eds. The Handbook of Economic Sociology (Princeton University Press, Princeton, US), 368-402.

Pratt MG (1998) To be or not to be? Central questions in organizational identification. Whetten DA, Godfrey PC, eds. Identity in Organizations: Building Theory through Conversations (Sage, Thousands Oaks, US), 171-207.

Putnam RD (1993) The prosperous community: Social capital and public life. The American Prospect 13 3542.

Rabe-Hesketh S, Skrondal A (2012) Multilevel and longitudinal modeling using Stata, Third ed (Stata Press, College Station, US).

Raffaelli M (1992) Sibling conflict in early adolescence. Journal of Marriage and the Family 54(3): 652-663.

Ridgeway CL (2011) Framed by Gender: How Gender Inequality Persists in the Modern World (Oxford University Press, Oxford, UK).

Roberts M, Whited T (2012) Endogeneity in empirical corporate finance. Constantinides M, Harris M, Stulz R, eds. Handbook of the Economics of Finance (Elsevier Science, Amsterdam), 493-572.

Rodríguez A, Nieto MJ (2016) Does R\&D offshoring lead to SME growth? Different governance modes and the mediating role of innovation. Strategic Management Journal 37(8): 1734-1753.

Rosenbaum P, Rubin D (1983) The central role of the propensity score in observational for causal effects. Biometrika 70(1): 41-55.

Rousseau DM, Sitkin SB, Burt RS, Camerer C (1998) Not so different after all: A cross-discipline view of trust. Academy of Management Review 23(3): 393-404.

Ruef M (2002) Strong ties, weak ties and islands: Structural and cultural predictors of organizational innovation. Industrial and Corporate Change 11(3): 427-449.

Ruef M (2010a) The Entrepreneurial Group: Social Identities, Relations, and Collective Action (Princeton University Press, Princeton, US).

Ruef M (2010b) Entrepreneurial groups. Landström H, Lohrke F, eds. Historical Foundations of Entrepreneurship Research (Edward Elgar, Cheltenham, UK), 205-228.

Ruef M, Aldrich H, Carter N (2003) The structure of founding teams: Homophily, strong ties, and isolation among US entrepreneurs. American Sociological Review 68(2): 195-222.

Schulze WS, Lubatkin MH, Dino RN (2003) Exploring the agency consequences of ownership dispersion among the directors of private family firms. Academy of Management Journal 46(2): 179-194.

Schulze WS, Lubatkin MH, Dino RN, Buchholtz AK (2001) Agency relationships in family firms: Theory and evidence. Organization Science 12(2): 99-116.

Segalen M (1986) The Historical Anthropology of the Family (Cambridge University Press, New York). 
Shane SA (1996) Hybrid organizational arrangements and their implications for firm growth and survival: A study of new franchisors. Academy of Management Journal 39(1): 216-234.

Shepherd D, Wiklund J (2009) Are we comparing apples with apples or apples with oranges? Appropriateness of knowledge accumulation across growth studies. Entrepreneurship Theory and Practice 33(1): 105-123.

Sirmon D, Hitt M (2003) Managing resources: Linking unique resources, management and wealth creation in family firms. Entrepreneurship Theory and Practice 27(4): 339-358.

Smith KG, Smith KA, Olian JD, Sims HP, O'Bannon DP, Scully JA (1994) Top Management Team Demography and Process: The Role of Social Integration and Communication. Administrative Science Quarterly 39(3): 412-438.

Smith SR, Hamon RR, Ingoldsby BB, Miller JE (2008) Exploring Family Theories (Oxford University Press Oxford, UK).

Stam W, Elfring T (2008) Entrepreneurial orientation and new venture performance: The moderating role of intra- and extraindustry social capital. Academy of Management Journal 51(1): 97-111.

Stinchcombe AL (1965) Social structures and organizations. March JG, ed. Handbook of Organizations (Rand McNally, Chicago, US), 142-193.

Stuart TE (2000) Interorganizational alliances and the performance of firms: A study of growth and innovation rates in a high-technology industry. Strategic Management Journal 21(8): 791-811.

Sullivan KT, Pasch LA, Johnson MD, Bradbury TN (2012) Social support, problem solving, and the longitudinal course of newly wed marriage. Journal of Personality and Social Psychology 98(4): 631-644.

Sutton J (1997) Gibrat's legacy. Journal of Economic Literature 35(1): 40-59.

Swidler A (2003) Talk of Love: How Culture Matters (The University of Chicago Press, Chicago, US).

Tsai W, Ghoshal S (1998) Social capital and value creation: The role of intrafirm networks. Academy of Management Journal 41(4): 464-476.

Uzzi B (1996) The sources and consequences of embeddedness for the economic performance of organizations: The network effect. American Sociological Review 61(4): 674-698.

Uzzi B (1997) Social structure and competition in interfirm networks: The paradox of embeddedness. Administrative Science Quarterly 42(1): 35-67.

Verver M, Koning J (2017) Toward a kinship perspective on entrepreneurship. Entrepreneurship Theory and Practice forthcoming.

Villalonga B, Amit R (2006) How do family ownership, control and management affect firm value? Journal of Financial Economics 80(2): 385-417.

Weick KE (1995) Sensemaking in Organizations (Sage Publications, Thousand Oaks, US).

Welter F (2011) Contextualizing entrepreneurship - conceptual challenges and ways forward. Entrepreneurship Theory and Practice 35(1): 164-184.

Wennberg K, Delmar F, McKelvie A (2016) Variable risk preferences in new firm growth and survival. Journal of Business Venturing 31(4): 408-427.

White L (2001) Sibling relationships over the life course: A panel analysis. Journal of Marriage and Family 63(2): 555-568.

Wiersema MF, Bantel KA (1992) Top management team demography and corporate strategic change. Academy of Management Journal 35(1): 91-121.

Wiklund J, Nordqvist M, Hellerstedt K, Bird M (2013) Internal versus external ownership transition in family firms: An embeddedness perspective. Entrepreneurship Theory and Practice 37(6): 1319-1340.

Wiklund J, Patzelt H, Shepherd D (2009) Building an integrative model of small business growth. Small Business Economics 32(4): 351-374.

Wright M, Stigliani I (2012) Entrepreneurship and growth. International Small Business Journal 31(1): 3-22.

Yang T, Aldrich H (2014) Who's the boss? Explaining gender inequality in entrepreneurial teams. American Sociological Review 79(2): 303-327.

Zellweger TM (2017) Managing the Family Business: Theory and Practice (Edward Elgar, Cheltenham, UK).

Zellweger TM, Kellermanns FW, Chrisman JJ, Chua JH (2012a) Family control and family firm valuations by family CEOs: The importance of intentions for transgenerational control. Organization Science 23(2): 851868.

Zellweger TM, Nason RS, Nordqvist M (2012b) From longevity of firms to transgenerational entrepreneurship of families introducing family entrepreneurial orientation. Family Business Review 25(2): 136-155. 


\section{Table 1 Correlations, Means, Standard Deviations, Minima, Maxima, and Variance Inflation Factors}

\begin{tabular}{|c|c|c|c|c|c|c|c|c|c|c|c|c|c|c|c|c|c|c|c|c|}
\hline & & Mean & SD & Min & Max & VIFs & 1 & 2 & 3 & 4 & 5 & 6 & 7 & 8 & 9 & 10 & 11 & 12 & 13 & 14 \\
\hline 1 & Firm Growth (t) & 0.050 & 0.179 & -1.263 & 1.645 & n.a. & & & & & & & & & & & & & & \\
\hline 2 & Turnover (ln) & 9.335 & 0.922 & 6.497 & 14.457 & 1.47 & -0.078 & & & & & & & & & & & & & \\
\hline 3 & Altman's Z-score & 4.195 & 2.431 & 0.065 & 32.463 & 1.21 & -0.043 & 0.207 & & & & & & & & & & & & \\
\hline 4 & Return on Assets (ln) & 2.150 & 0.931 & -2.303 & 5.191 & 1.12 & 0.059 & 0.047 & 0.217 & & & & & & & & & & & \\
\hline 5 & Team Age (mean) & 48.154 & 8.370 & 21.000 & 73.500 & 1.31 & -0.098 & -0.041 & -0.055 & -0.030 & & & & & & & & & & \\
\hline 6 & Full-Time Owners in $\%$ & 0.935 & 0.164 & 0.200 & 1.000 & 1.32 & -0.043 & 0.129 & 0.033 & 0.019 & -0.033 & & & & & & & & & \\
\hline 7 & Potential Heirs (ln) & 1.338 & 0.532 & 0.000 & 3.807 & 1.40 & 0.002 & 0.116 & -0.076 & -0.023 & -0.079 & 0.032 & & & & & & & & \\
\hline 8 & Team years of Education (mean) & 11.237 & 1.959 & 6.000 & 18.000 & 1.86 & 0.046 & 0.000 & 0.005 & 0.072 & -0.190 & -0.049 & -0.015 & & & & & & & \\
\hline 9 & Proportion Employees w. Higher Educ. & 0.177 & 0.230 & 0.000 & 1.000 & 2.02 & -0.021 & -0.022 & 0.022 & 0.123 & 0.020 & 0.054 & 0.008 & 0.607 & & & & & & \\
\hline 10 & Urban Region & 0.137 & 0.344 & 0.000 & 1.000 & 1.08 & 0.044 & 0.021 & 0.040 & 0.058 & -0.057 & 0.016 & 0.013 & 0.143 & 0.184 & & & & & \\
\hline 11 & Lambda & 1.046 & 0.746 & 0.000 & 4.213 & 1.70 & -0.030 & 0.439 & 0.320 & 0.217 & -0.102 & 0.084 & -0.020 & -0.004 & 0.028 & 0.060 & & & & \\
\hline 12 & Spousal Entrepreneurs & 0.664 & 0.472 & 0.000 & 1.000 & 1.42 & 0.036 & -0.171 & 0.072 & 0.060 & 0.293 & -0.128 & -0.365 & 0.090 & 0.128 & -0.033 & -0.033 & & & \\
\hline 13 & Firm Age (ln) & 2.088 & 0.911 & 0.000 & 3.045 & 1.27 & -0.141 & 0.190 & -0.025 & -0.064 & 0.185 & 0.109 & 0.105 & -0.147 & -0.161 & -0.077 & 0.057 & -0.175 & & \\
\hline 14 & Number of Owners & 2.330 & 1.087 & 2.000 & 25.000 & 1.33 & 0.013 & 0.120 & -0.028 & 0.040 & -0.065 & -0.001 & 0.424 & 0.111 & 0.200 & 0.103 & 0.019 & -0.130 & 0.048 & \\
\hline 15 & Heterogeneity in Team Industry Experience & 0.323 & 0.455 & 0.000 & 4.899 & 1.39 & 0.106 & -0.095 & -0.027 & 0.043 & -0.090 & -0.467 & 0.004 & 0.092 & 0.013 & 0.002 & -0.041 & 0.161 & -0.193 & 0.076 \\
\hline
\end{tabular}

Note: All correlations stronger than \pm 0.029 are significant at the $5 \%$ level or lower. 


\section{TABLE 2 Generalized Estimation Equation Regressions for Firm Growth}

\begin{tabular}{|c|c|c|c|c|}
\hline Dependent Variable: Firm Growth & Model 1 & Model 2 & Model 3 & Model 4 \\
\hline \multirow[t]{2}{*}{ Turnover (ln) } & $-0.0096^{* * *}$ & $-0.0096^{* * *}$ & $-0.0095 * * *$ & $-0.0094 * * *$ \\
\hline & $(0.0026)$ & $(0.0026)$ & $(0.0026)$ & $(0.0026)$ \\
\hline \multirow[t]{2}{*}{ Altman's Z-Score } & $-0.0033 * * *$ & $-0.0033 * * *$ & $-0.0033 * * *$ & $-0.0033 * * *$ \\
\hline & $(0.0009)$ & $(0.0009)$ & $(0.0009)$ & $(0.0009)$ \\
\hline \multirow[t]{2}{*}{ Return on Assets (ln) } & $0.0127 * * *$ & $0.0126^{* * *}$ & $0.0127 * * *$ & $0.0127 * * *$ \\
\hline & $(0.0022)$ & $(0.0022)$ & $(0.0022)$ & $(0.0022)$ \\
\hline \multirow[t]{2}{*}{ Team Age (mean) } & $-0.0016^{* * *}$ & $-0.0016^{* * *}$ & $-0.0016^{* * *}$ & $-0.0016^{* * *}$ \\
\hline & $(0.0003)$ & $(0.0003)$ & $(0.0003)$ & $(0.0003)$ \\
\hline \multirow[t]{2}{*}{ Full-Time Owners in \% } & 0.0187 & 0.0187 & 0.0184 & 0.0218 \\
\hline & $(0.0137)$ & $(0.0137)$ & $(0.0137)$ & $(0.0138)$ \\
\hline \multirow[t]{2}{*}{ Potential Heirs (ln) } & 0.0056 & 0.0052 & 0.0059 & 0.0052 \\
\hline & $(0.0044)$ & $(0.0044)$ & $(0.0044)$ & $(0.0044)$ \\
\hline \multirow[t]{2}{*}{ Team Years of Education (mean) } & $0.0058 * * *$ & $0.0058 * * *$ & $0.0058 * * *$ & $0.0059 * * *$ \\
\hline & $(0.0014)$ & $(0.0014)$ & $(0.0014)$ & $(0.0014)$ \\
\hline \multirow[t]{2}{*}{ Proportion Employees w. Higher Education } & $-0.0808 * * *$ & $-0.0811 * * *$ & $-0.0806 * * *$ & $-0.0808 * * *$ \\
\hline & $(0.0121)$ & $(0.0121)$ & $(0.0121)$ & $(0.0121)$ \\
\hline \multirow[t]{2}{*}{ Urban Region } & $0.0226 * * *$ & $0.0230 * * *$ & $0.0227 * * *$ & $0.0227 * * *$ \\
\hline & $(0.0059)$ & $(0.0059)$ & $(0.0059)$ & $(0.0059)$ \\
\hline \multirow[t]{2}{*}{ Lambda } & -0.0039 & -0.0040 & -0.0039 & -0.0040 \\
\hline & $(0.0034)$ & $(0.0034)$ & $(0.0034)$ & $(0.0034)$ \\
\hline \multirow[t]{2}{*}{ Firm Age (ln) } & $-0.0229 * * *$ & $-0.0144 * * *$ & $-0.0229 * * *$ & $-0.0230 * * *$ \\
\hline & $(0.0024)$ & $(0.0040)$ & $(0.0024)$ & $(0.0024)$ \\
\hline \multirow[t]{2}{*}{ Number of Owners } & 0.0028 & 0.0029 & $0.0054+$ & 0.0032 \\
\hline & $(0.0021)$ & $(0.0021)$ & $(0.0029)$ & $(0.0021)$ \\
\hline \multirow[t]{2}{*}{ Heterogeneity in Team Industry Experience } & $0.0225^{* * *}$ & $0.0224 * * *$ & $0.0221 * * *$ & 0.0077 \\
\hline & $(0.0051)$ & $(0.0050)$ & $(0.0051)$ & $(0.0090)$ \\
\hline \multicolumn{5}{|l|}{ Independent Variables } \\
\hline \multirow{2}{*}{ H1: Spousal Entrepreneurs } & $0.0159 * *$ & $0.0436 * * *$ & $0.0274 * *$ & $0.0106+$ \\
\hline & $(0.0050)$ & $(0.0114)$ & $(0.0103)$ & $(0.0056)$ \\
\hline \multicolumn{5}{|l|}{ Moderating Effects } \\
\hline \multirow[t]{2}{*}{ H 2: Spousal Entrepreneurs x Firm Age (ln) } & & $-0.0126 * *$ & & \\
\hline & & $(0.0047)$ & & \\
\hline \multirow[t]{2}{*}{ H 3: Spousal Entrepreneurs x Number of Owners } & & & -0.0047 & \\
\hline & & & $(0.0037)$ & \\
\hline \multirow[t]{2}{*}{$\begin{array}{l}\text { H 4: Spousal Entrepreneurs x Heterogeneity in Team Industry } \\
\text { Experience }\end{array}$} & & & & $0.0205^{*}$ \\
\hline & & & & $(0.0102)$ \\
\hline \multirow[t]{2}{*}{ Constant } & $0.1516 * * *$ & $0.1328 * * *$ & $0.1447 * * *$ & $0.1497 * * *$ \\
\hline & $(0.0338)$ & $(0.0345)$ & $(0.0342)$ & $(0.0338)$ \\
\hline Firm-Year Observations & 8,162 & 8,162 & 8,162 & 8,162 \\
\hline Firm Observations & 4,900 & 4,900 & 4,900 & 4,900 \\
\hline Number of Years & 3 & 3 & 3 & 3 \\
\hline Scale Parameter & 0.0304 & 0.0304 & 0.0304 & 0.0304 \\
\hline Wald Chi-Square & $432.1 * * *$ & $439.75 * * *$ & $433.82 * * *$ & 436.36 **** \\
\hline
\end{tabular}

Note: Industry controls are included but not reported; Standard errors in parentheses; $+\mathrm{p}<0.1 *^{*} \mathrm{p}<0.05 ; * * \mathrm{p}<0.01 ; * * * \mathrm{p}<$ 0.001 . 
FIGURE 1 Interaction of Firm Age and Spousal Entrepreneurs and the Impact on Firm Growth

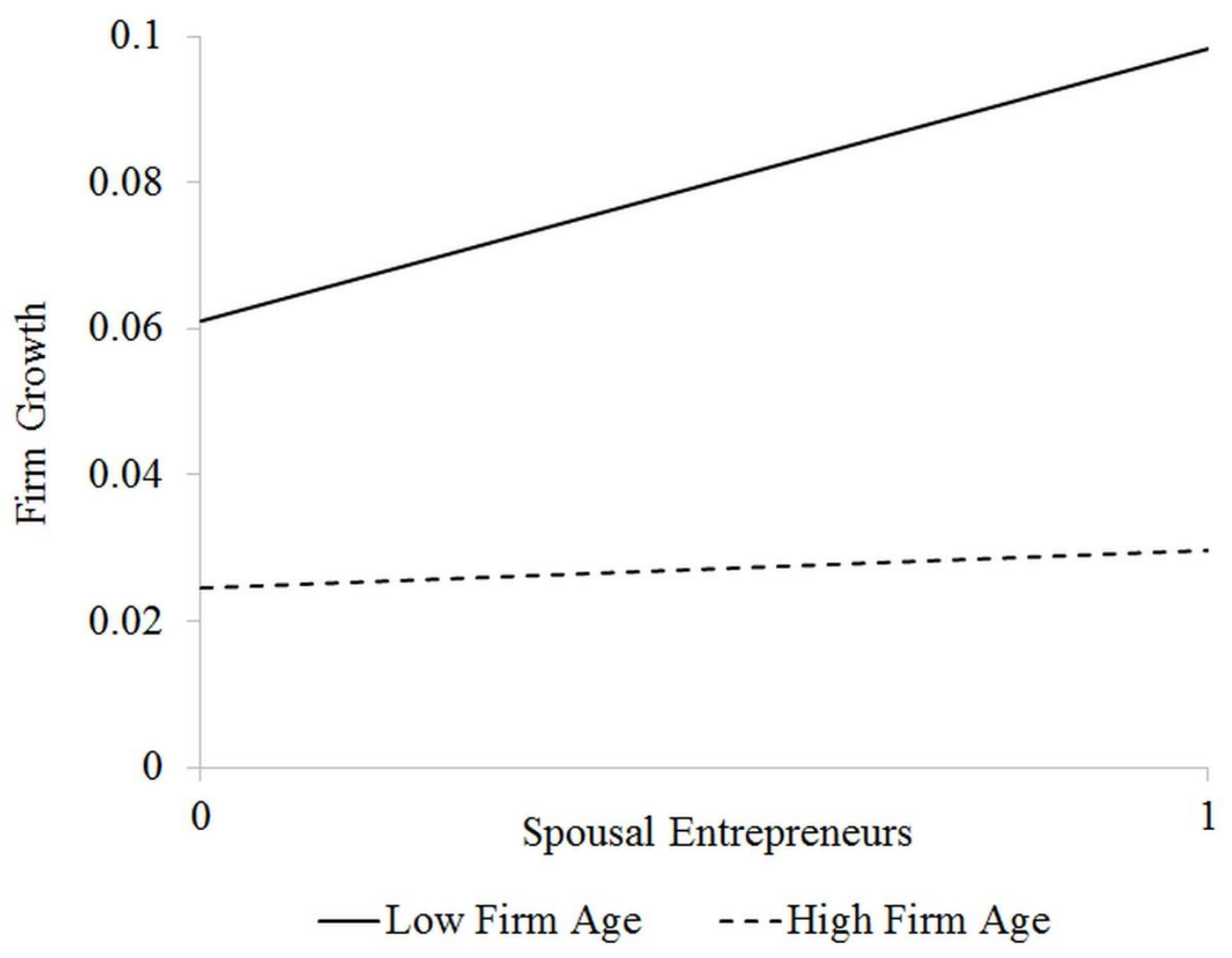


FIGURE 2 Interaction of Heterogeneity in Team Industry Experience and Spousal Entrepreneurs and the Impact on Firm Growth

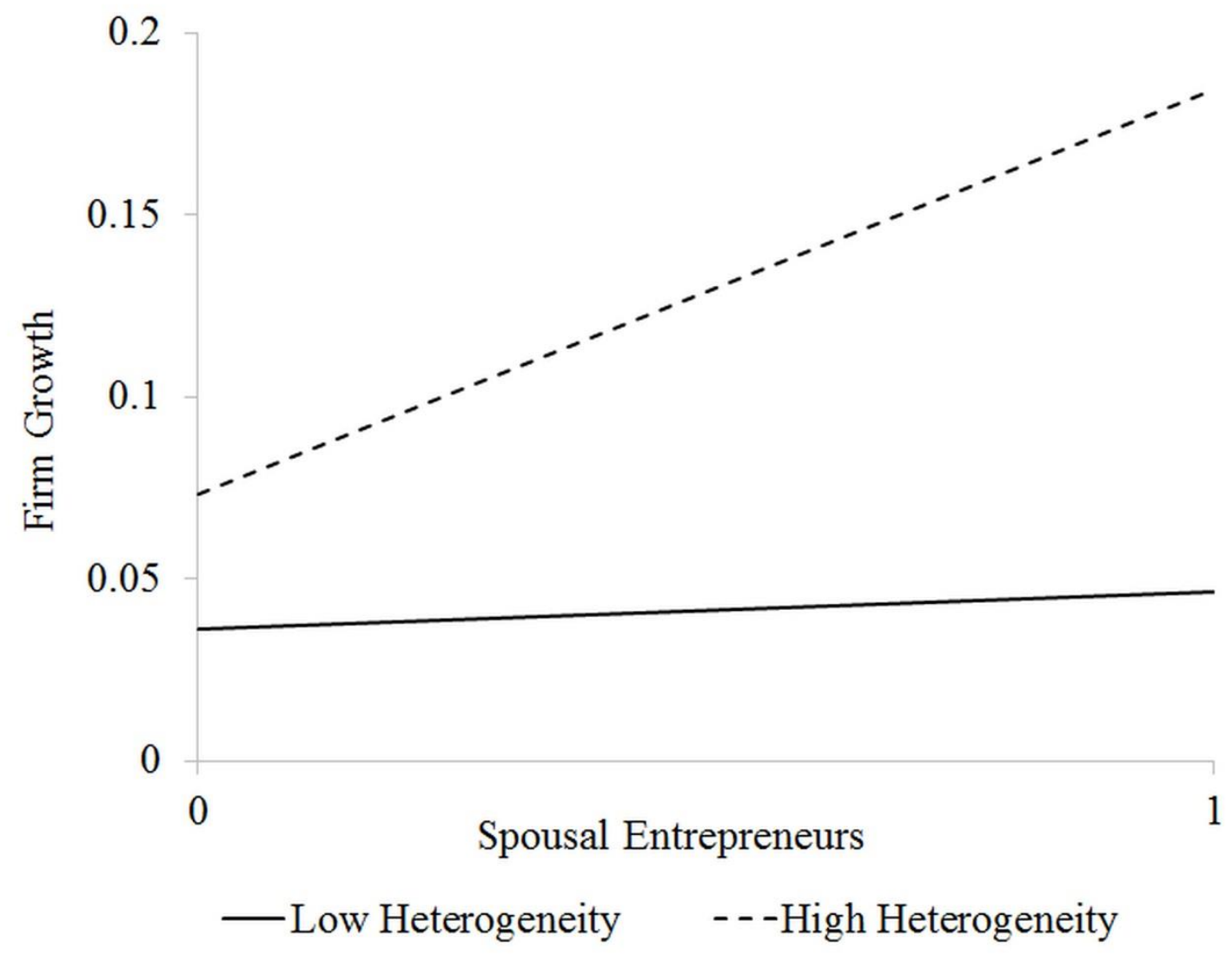

